\title{
Global Action on SDGs: Policy Review and Outlook in a Post-Pandemic Era
}

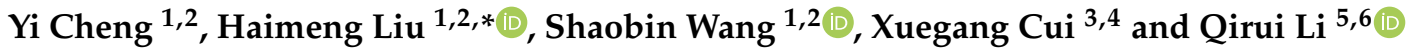 \\ 1 Institute of Geographical Sciences and Natural Resources Research, Chinese Academy of Sciences, \\ Beijing 100101, China; chengy.14s@igsnrr.ac.cn (Y.C.); wangshaobin@igsnrr.ac.cn (S.W.) \\ 2 College of Resources and Environment, University of Chinese Academy of Sciences, Beijing 100049, China \\ 3 Post-Doctoral Research Station of Theoretical Economics, Shenzhen University, Shenzhen 518060, China; \\ cuixg.16b@igsnrr.ac.cn \\ 4 Qianhai Institute for Innovative Research, Shenzhen 518052, China \\ 5 Africa Multiple Cluster of Excellence, University of Bayreuth, 95440 Bayreuth, Germany; \\ qirui.li@uni-bayreuth.de \\ 6 Bayreuth Centre of Ecology and Environmental Research, University of Bayreuth, 95448 Bayreuth, Germany \\ * Correspondence: liuhm@igsnrr.ac.cn
}

Citation: Cheng, Y.; Liu, H.; Wang, S. Cui, X.; Li, Q. Global Action on SDGs: Policy Review and Outlook in a Post-Pandemic Era. Sustainability 2021, 13, 6461. https://doi.org/ $10.3390 /$ su13116461

Academic Editor: Antonio Boggia

Received: 7 May 2021

Accepted: 4 June 2021

Published: 7 June 2021

Publisher's Note: MDPI stays neutral with regard to jurisdictional claims in published maps and institutional affiliations.

Copyright: (c) 2021 by the authors Licensee MDPI, Basel, Switzerland. This article is an open access article distributed under the terms and conditions of the Creative Commons Attribution (CC BY) license (https:// creativecommons.org/licenses/by/ $4.0 /)$.

\begin{abstract}
The 2030 Agenda for Sustainable Development provided brand new goals and action targets for human well-being and development, but the COVID-19 pandemic has cast a shadow on the implementation of the Sustainable Development Goals (SDGs). It is therefore essential to provide a reference for making policy adjustments and transformations to promote the realization of SDGs in the post-pandemic era. Based on a literature review of the progress and policies of SDGs across countries worldwide, we find that research on sustainable policies has rapidly increased since the SDGs issued in 2015 with particular focuses on eco-environment, sustainable policies, green economy, sanitation and health, and water sanitation. Most countries are in the process of nationalization, institutionalization, and universalization of the SDGs through incorporating the SDGs into national development frameworks, enabling extensive participation and negotiation mechanisms, and promoting the SDGs' national publicity. Countries of different economic and institutional backgrounds demonstrate divergent development pathways, priorities, measures, and progress in the implementation of SDGs. Despite significant global progress during the last five years, the North-South divide emerges in the policy action and achievement of SDGs. The least developed countries in sub-Sahara Africa and South Asia appear to be difficult or even unable to implement the SDGs and monitor the progress. In the post-pandemic era, particular attention shall be given to integrating SDGs and achieve synergy among goals, concretizing short-and mediumterm priorities toward the SDGs targets for all countries, strengthening multilateralism and global cooperation among countries and continents, providing reliable data and approaches for real-time impact assessment and process monitoring, and promoting an inclusive engagement and integrative implementation with multiple stakeholders and consortiums.
\end{abstract}

Keywords: SDGs; sustainable development; 2030 agenda; policy transformations; human well-being; global cooperation; goal interactions; COVID-19

\section{Introduction}

Sustainable development is the common goal of humankind and is necessary to achieve human well-being. In 2015, 193 countries around the world passed the "Transforming Our World: The United Nations 2030 Agenda for Sustainable Development" at the United Nations Sustainable Development Summit and proposed a set of 17 sustainable development goals (SDGs) and 169 targets to guide international development, specifically with regard to society, the economy, and the environment. This is the inheritance of the agenda of the new millennium. The 17 goals revolve around themes that are closely related to human prosperity, such as poverty, 
equality, hunger, climate change, resources, and the environment [1]. The new agenda calls on all countries to take action now and work toward achieving the 17 SDGs in the next 15 years. While the SDGs are intended to be achieved on a global scale, their action implementation depends on the level at which countries prioritize them, and on how sustainability issues compete with a country's other challenges [2].

SDGs require the joint participation and promotion of science, policies, tools, etc. The implementation of policies is a critical and leading measure in achieving the SDGs. UN specialized agencies, enterprises, various social groups and stakeholders, and most importantly, governments, have initiated extensive actions and formulated many policies and measures aimed at the SDGs [3]. There are some policy studies on the realization of SDGs, but they are mainly focused on specific countries (regions) or specific areas or cities, such as the European Union [4], Ganges River basin [5], Amazonia [6], Pearl River Delta [7], India [8], New Zealand [9], as well as specific fields such as decent work [10], agriculture development, public health [11], energy [12], climate change [13]. The current analysis of various global policies is still seriously inadequate.

Since the spring of 2020, the COVID-19 pandemic has dramatically influenced the human socioeconomic system. Up until 6 April 2021, WHO has reported more than 132 million confirmed cases of COVID-19 and 2,871,642 deaths. The World Bank estimates that the global economy would shrink by $5.2 \%$ in 2020 , which would be the deepest recession since World War Two [14], and WHO Director-General Tedros stated that the impact of the coronavirus will be felt for decades to come [15]. The COVID-19 pandemic has been a global threat with great economic and social challenges. Two-thirds of the 169 SDG targets are either under threat as a result of this pandemic or not well implemented to mitigate its impacts [16], for example, inequality [17], poverty [18], agricultural and food security $[19,20]$, drinking water and sanitation [21], biodiversity conservation [22]. COVID19 is exposing the fragility of the SDGs and will have a significant negative impact on most goals as global depression looms [16,23]. Making policy adjustments and transformations to promote the implementation of global SDGs in the post-pandemic era is a major issue.

This article begins with a bibliometric summary on SDGs and Policy (Section 2). Section 3 reviews and discusses the literature on policies about SDGs in OECD countries, BRICS countries (Brazil, Russia, India, China, and South Africa), and least developed countries (LDCs), and also comments on the progress and policies of SDG targets in different countries. The final section discusses the transformation path as well as recommendations for global SDGs in a post-pandemic era. This is important for exploring science-policy-practice interfaces, mitigating the negative effects of the pandemic as soon as possible, and moving toward the 2030 SDGs. The full names of abbreviations used in this article can be found in Abbreviations Section.

\section{Bibliometric Analysis}

English papers written in the past 40 years were obtained through the SCI/SSCI database of the Web of Science. To retrieve as much comprehensive and accurate literature in the field of SDGs policy action research as possible, we used title keywords to search. The search format is designed as: $(\mathrm{TI}=(\mathrm{SDG} \times \mathrm{OR}$ sustainable development goal $\times \mathrm{OR}$ 2030 agenda OR sustainable development $)$ AND TI $=($ polic $\times$ OR action OR plan) $)$ AND LANGUAGE: (all languages) AND DOCUMENT TYPES: (all document types) Indexes = SCI-EXPANDED, SSCI, CPCI-S, CPCI-SSH, Timespan $=1981-2020$. The final search yielded 1402 English documents found in the WOS core database from 1981 to 2020.

Figure 1 shows the changes in the number of articles published about "SDGs and Policy" from 1981 to 2020. It was found that after the implementation of the UN SDGs in 2015, the number of related articles has grown rapidly, from 49 articles in 2014 to 147 articles in 2020. Research on sustainable development emerged in the 1980s, and the research on sustainable development policies has grown rapidly since the 21st century. The occurrence year and frequency of Subject terms on "SDGs and Policy" from 1981 to 2020 were identified using Citespace (Table 1). It demonstrates that "sustainable development" has always been the core keyword of research, as it has the highest frequency of occurrence. 
Sustainable development policy and environmental policy became hot spots in 1997, and green economy, energy policy, and climate change began to become hot spots in 2011. In recent years, climate policy, cultural policy, and climate action have attracted attention from scholars. The global climate policy and SDG agendas are highly interconnected [24], and cultural policy can and should play a more active role in shaping social change [25].

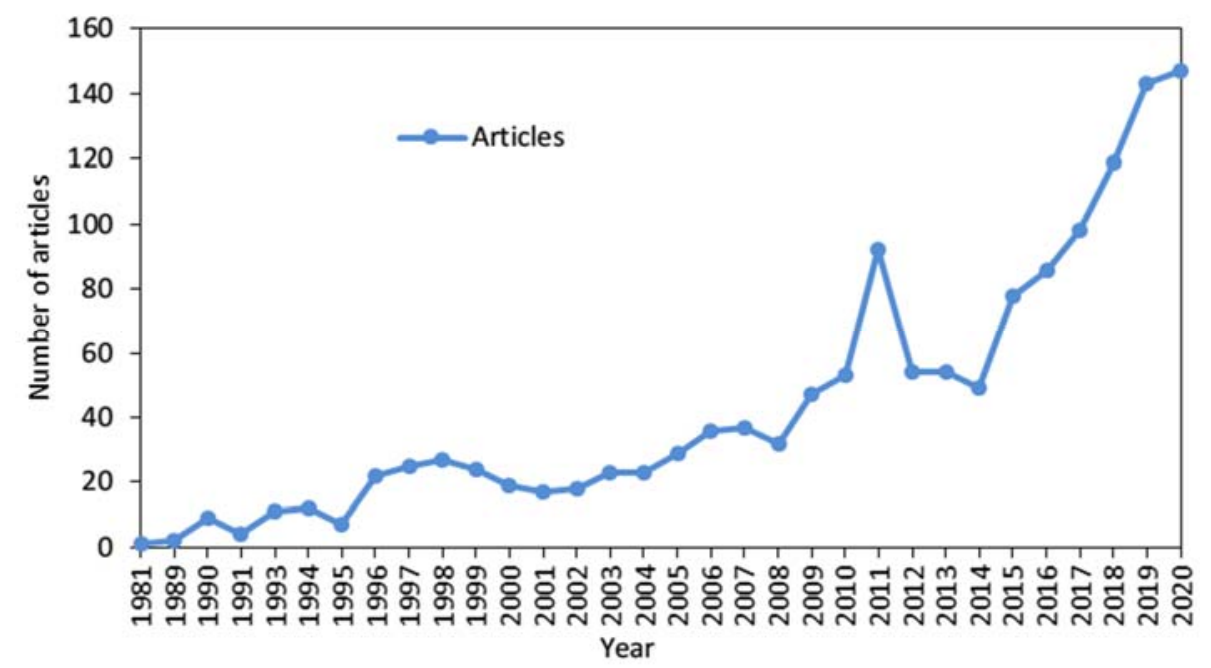

Figure 1. Number of articles published about "SDGs and Policy", 1981-2020.

Since the implementation of the UN SDGs in 2015, the Web of Science core library has published 2218 articles related to SDGs. The search format is designed as: $(\mathrm{TI}=(\mathrm{SDG} \times \mathrm{OR}$ sustainable development goal $\times$ OR 2030 agenda)) AND LANGUAGE: (all languages) AND DOCUMENT TYPES: (all document types) Indexes = SCI-EXPANDED, SSCI, CPCI-S, CPCISSH, Timespan $=2015-2020$. Using the VOSviewer software to conduct keyword co-occurrence network analysis, we found that the most frequently cited articles around the world focus on the eco-environment, sustainable policies, green economy, health, water sanitation, and other topics in the SDGs, and the different topics are closely related (Figure 2). According to the keyword co-occurrence, there are three research subnetworks, which are displayed in different colors in Figure 2. One is related to the SDGs' priority in health, gender equality, and children; the second is the water-food ecosystem nexus; the third is about the measures, challenges, and difficulties of SDGs attainment.

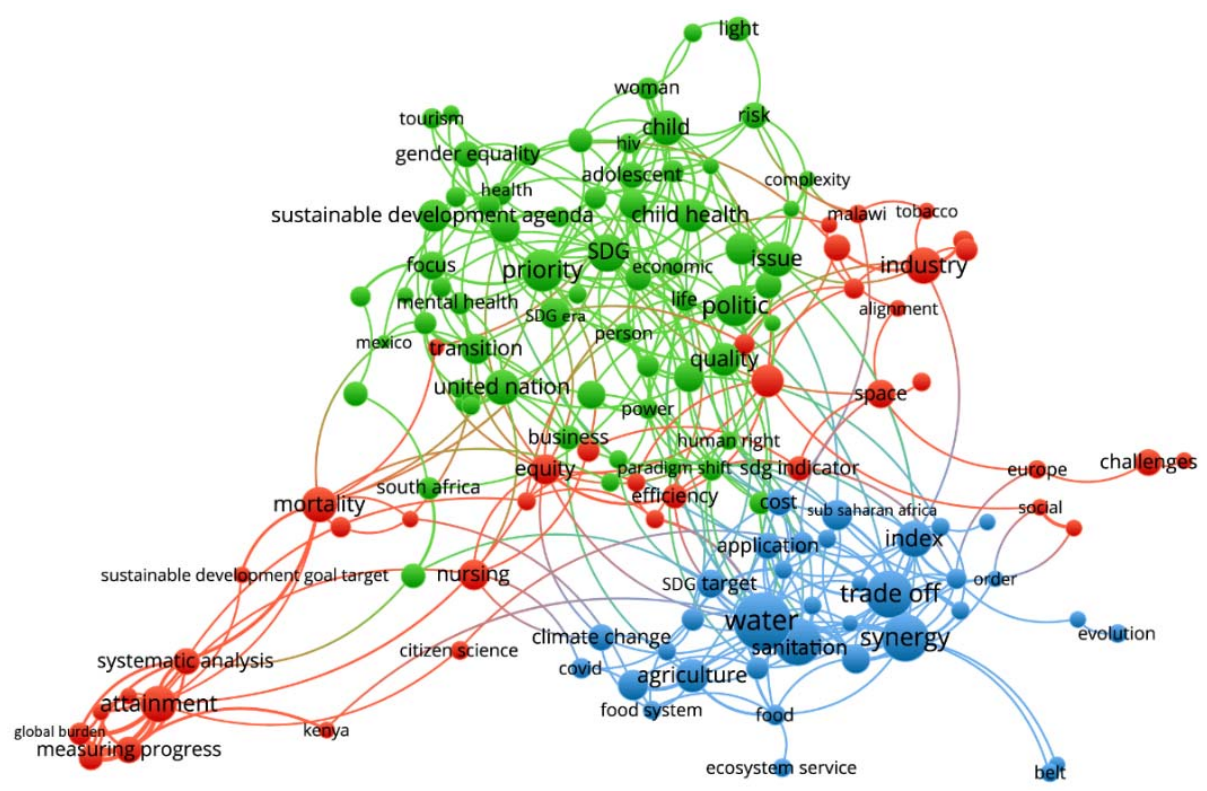

Figure 2. Keyword co-occurrence network of "SDGs" related literature, 2016-2020. 
Table 1. Subject terms evolution and frequency regarding "SDGs and Policy", 1981-2020.

\begin{tabular}{|c|c|c|}
\hline Subject Terms (Title + Keywords) & Occurrence Year & Number of Articles \\
\hline sustainable development & 1981 & 416 \\
\hline policy implications & 1989 & 4 \\
\hline energy policy & 1994 & 9 \\
\hline sustainable development plan & 1995 & 5 \\
\hline urban planning & 1996 & 6 \\
\hline achieving sustainable development & 1996 & 5 \\
\hline sustainable development policy & 1997 & 31 \\
\hline environmental policy & 1997 & 17 \\
\hline policy integration & 1997 & 3 \\
\hline agricultural policy & 1999 & 5 \\
\hline European union & 2001 & 12 \\
\hline strategic planning & 2001 & 8 \\
\hline spatial planning & 2001 & 4 \\
\hline public participation & 2001 & 3 \\
\hline economic growth & 2003 & 3 \\
\hline sustainable rural development & 2003 & 3 \\
\hline policy framework & 2003 & 3 \\
\hline cohesion policy & 2004 & 3 \\
\hline sustainable urban development & 2005 & 9 \\
\hline sustainable development planning & 2006 & 9 \\
\hline policy coherence & 2006 & 3 \\
\hline local communities & 2008 & 4 \\
\hline development policy & 2010 & 4 \\
\hline sustainable tourism & 2010 & 3 \\
\hline green economy & 2011 & 32 \\
\hline useful way & 2011 & 30 \\
\hline energy policy & 2011 & 30 \\
\hline climate change & 2011 & 11 \\
\hline renewable energy & 2011 & 4 \\
\hline natural resources & 2011 & 4 \\
\hline sustainable energy development & 2011 & 4 \\
\hline action research & 2012 & 5 \\
\hline climate policy & 2014 & 3 \\
\hline sustainable development goal & 2016 & 40 \\
\hline cultural policy & 2017 & 5 \\
\hline climate action & 2018 & 3 \\
\hline
\end{tabular}

\section{Policy Review of Different Countries to Implement the SDGs}

This article summarizes the main practices of OECD countries, BRICs countries, and LDCs in implementing the 2030 Agenda for Sustainable Development, by their development levels. As part of its follow-up and review mechanisms, the 2030 Agenda encourages member states to "conduct regular and inclusive reviews of progress at the national and 
subnational levels, which are country-led and country-driven" [26]. The voluntary national reviews (VNRs) are an opportunity for countries to share their successes, challenges, and lessons learned, accelerating the implementation of the 2030 Agenda. Although they are not compulsory, as of April 2021, 168 countries have submitted VNRs to the annual meeting of the High-Level Political Forum on Sustainable Development. References in this section come from various kinds of government documents, research papers, and reports, in addition to the VNRs submitted by various countries.

\subsection{OECD Countries}

OECD countries are generally concerned about global natural environmental issues. OECD countries are at an advanced stage in achieving various SDGs (e.g., Sweden, Denmark, Norway, and Switzerland). For individual goals, such as No Poverty (Goal 1) and Zero Hunger (Goal 2), efforts are given to improving social welfare, especially for vulnerable groups such as children and the disabled. Iceland and Switzerland prioritize Sustainable Consumption and Production (Goal 12) in their policy implementation. Canada emphasizes No Poverty (Goal 1), Gender Equality (Goal 5), Decent Work and Economic Growth (Goal 8), Sustainable Consumption and Production (Goal 12), Climate Action (Goal 13), and Life below Water (Goal 14). Austria regards Good Health and Well-being (Goal 3), Gender Equality (Goal 5), and Climate Action (Goal 13) as the priority for achieving SDGs. Denmark adopts Industry, Innovation, and Infrastructure (Goal 9), Life below Water (Goal 14), and Life on Land (Goal 15). Norway takes Quality Education (Goal 4), Decent Work and Economic Growth (Goal 8), and Sustainable Consumption and Production (Goal 12) as priority implementation areas. Meanwhile, Iceland believes that the realization of Sustainable Consumption and Production (Goal 12) and Climate Action (Goal 13) is the current challenge, and Denmark has challenges in the realization of Industry, Innovation, and Infrastructure (Goal 9), Sustainable Cities and Communities (Goal 11), and Sustainable Consumption and Production (Goal 12).

Most countries have responded to the United Nations "the 2030 Agenda" and are launching suitable action plans. In 2016, the European Union released a sustainable development package plan along with "The Future of Sustainable Europe: The EU's response to the 2030 Agenda for Sustainable Development," which systematically explained the EU's measures to implement the goals of the 2030 Agenda for Sustainable Development [27]. The UK government published “Agenda 2030: The UK Government's approach to delivering the Global Goals for Sustainable Development-at home and around the world" [28], which provided an approach to delivering the Global Goals for Sustainable Development at home and around the world. Spain is committed to achieving the highest level of SDGs, focusing national public policy and political priorities on achieving SDGs [29]. The Swedish government's ambition is to be a leader in implementing the 2030 Agenda-both at home and globally [30].

OECD countries are widely participating in international assistance and are committed to the realization of global SDGs. For example, the UK issued the "British Aid Strategy" in 2015 [31]. The US Agency for International Development is committed to the realization of global SDGs through existing initiatives and programs such as "Feed the Future", "Global Labor Plan", and the "US Government Education Strategy" [32]. Canada announced its new Feminist International Assistance Policy in 2017 [33]. Norway actively provides marine environmental protection assistance to developing countries by implementing multilateral mechanisms such as the Green Climate Fund, providing climate financing to vulnerable countries in LDCs, supporting the promotion of renewable energy in African and Asian countries, etc. [34]. Austria uses its position as the official seat of international organizations to promote sustainable development on a global level [35]. Germany is committed to the goal of using $0.7 \%$ of its gross national income for ODA within the 2030 Agenda and plans to double international climate financing by 2020 [36].

OECD countries are committed to developing global partnerships and promoting the implementation of the SDGs through extensive cooperation. With capital, talents, and tech- 
nology, OECD countries will promote the deepening of global development partnerships by leading the "Global Partnership for Effective Development Cooperation" and occupying a dominant position in the international order for solving global environmental problems. This will facilitate exchanges among its member states as well as deepen international cooperation with other developing countries. Norway maintains substantial investments in global health, women, and children, establishing partnerships in the private sector, vaccine alliances, and global education [34]. Switzerland has contributed to the effort by strengthening domestic resource mobilization and capacity building, and by promoting a universal, rules-based, multilateral trading system [37].

\subsection{BRICS Countries}

Government plans dominate in the process of implementing SDGs. India has fully coordinated and led the realization of SDGs through NITI Aayog, chaired by the Prime Minister (https:/ / niti.gov.in/, accessed on 25 May 2021). China incorporated SDGs into the "14th Five-Year" National Economic and Social Development Plan Outline, translated SDGs into specific tasks in the economic, social, and environmental fields [38], and eradicated absolute poverty by 2020 under the long-term efforts of the government, which provided a strong impetus to the cause of global poverty reduction [39]. Brazil connects SDG targets and indicators with Plano Plurianual (PPA) attributes, linking the medium-term vision of government action with the expectation of implementing the commitments contained in the SDGs. South Africa has established the Inter-Ministerial Committee on the Sustainable Development Agenda and the National Development Stakeholder Forum to strengthen the dialogue on SDGs [40]. Russia has 12 National Projects and has created the Comprehensive Plan for the Modernization and Expansion of Main Infrastructure, which is aimed at SDG achievement [41].

BRICS countries are actively involved in the development of international cooperation and regional cooperation. The scope of partnership among different countries depends on national strength. China and India tend to strengthen their global partnerships, but South Africa and Brazil tend to strengthen partnerships at the regional level. China has promoted the establishment of a global partnership for the implementation of SDGs through the "Belt and Road" initiative [42]. India has actively contributed to the crafting of policy coalitions such as the International Solar Alliance, Coalition for Disaster Resilience Infrastructure, India-Africa Forum Summit, India-CARICOM, the Bay of Bengal Initiative for Multi-Sectoral Technical and Economic Cooperation, etc. [43]. Russia actively promotes regional cooperation among the countries of Eastern Europe, Transcaucasian and Central Asian countries, and the countries of the Asia-Pacific region. The implementation of such cooperation is reflected in the framework of multilateral and regional associations such as EAEU, BRICS, SCO, ASEAN, ASEM, and APEC [41]. South Africa would assist Africa in coordinating representation in the United Nations Multi-Stakeholder Forum for Science, Technology, and Innovation for the SDGs, and has also been active in supporting collaborative research projects with other African countries to improve the use of technology in addressing the SDGs [43].

BRICS countries are generally willing to provide international support within their capacity. China provides voluntary support to developing countries in terms of funding, technology, and capacity building, and provides beneficial public products for global development. In 2017, China announced that it would provide CNY 2 billion of emergency food aid to developing countries along the "Belt and Road" and invest USD 1 billion in the South-South Cooperation Assistance Fund, as well as support the implementation of 100 Happy Home Projects, 100 Anti-Poverty Projects, 100 Health Recovery Projects in countries along the "Belt and Road" (http:/ / www.chinadaily.com.cn/china/2017-05/16 / content_29359377.htm, accessed on 25 May 2021) This encouraged the Asian Infrastructure Investment Bank and the BRICS New Development Bank to play a greater role in providing international support [44]. According to the Ministry of Finance of the Russian Federation, the 2018 federal budget expenditures classified as official development assistance (ODA) 
under the OECD methodology reached almost USD 1 billion [41], and the main recipients of such assistance are Latin American and CIS countries. India has committed a total of USD 150 million over a decade to the India-UN Development Partnership Fund [43].

\subsection{Least Developed Countries (LDCs)}

LDCs tend to prioritize the implementation of basic and urgent SDGs. Due to limited financial and facility conditions, LDCs tend to give priority to achieving goals for solving people's basic needs. For example, in Malawi, more efforts have been dedicated to Health (Goal 3), Education (Goal 4), Gender (Goal 5), Clean Water and Sanitation (Goal 6), Sustainable Cities (Goal 11), and Strong Institutions (Goal 16) [45]. Sierra Leone has prioritized Education (Goal 4) and Access to Justice (Goal 16) [46]. Bhutan prioritizes No Poverty (Goal 1), Climate Action (Goal 13), and Life on Land (Goal 15) [47]. The reduction of poverty and hunger are at the core of Zambia's national development agenda [48].

LDCs actively sought international support. The Turkish President called on the UN member states to maintain meaningful ODA support, which constitutes the most important source of funding for LDCs [49]. The international community has pledged to provide Afghanistan with a total of USD 15.2 billion in aid for five years (2017-2021) [50]. The United Nations Country Team (UNCT), including IMF, World Bank, and African Development Bank continue to play a key role in the development of Sierra Leone. In 2017, the total ODA by the top 10 donors in Sierra Leone amounted to USD 490.3 million [46]. ODA funds about 34 percent of Bhutan's development programs, and Bhutan has been effectively utilizing ODA to the maximum benefit [47].

There are some obstacles to the implementation of the SDGs, which include insufficient government finances, a large population, insufficient capacity to collect statistics, and a shortage of government enforcement. Implementation capacity gaps, comprising perceptions, technical know-how, technology, finances, etc. are also considered serious challenges to be dealt with in the effort to eradicate poverty in all its manifestations by 2030 [51]. For instance, $70 \%$ of the total expenditure budget of Ethiopia is being used to fund five sectors: education, health, agriculture, water and sanitation, and rural road construction, which means that the other SDGs lack financial support, and thus are difficult to achieve [52]. The sheer number of poor people is also a huge challenge for Bangladesh [53].

\subsection{SDG Policy Reviews across Different Countries}

\subsubsection{Main Policy Measures to Achieve SDGs in Various Countries}

Creating ownership of the SDGs. The 2030 Agenda is a comprehensive agenda that requires all stakeholders' cooperation and contributions to ensure an open and transparent participatory process. To achieve the SDGs by 2030, innovative practices and solutions including multi-stakeholder cooperation and diversification of funding sources should be developed [54]. To realize this, it is important to ensure the ownership of all relevant parties [49]. Governments in most countries are responsible for the implementation of the 2030 Agenda by making political commitments and mobilizing stakeholders' involvement. For example, Bhutan developed an SDGs communications strategy to create further awareness and ownership of SDGs [47]. Laos implemented policy decisions to ensure ownership of the SDGs [55]. The government of Thailand invited all sectors at all levels to engage in the VNR process and join hands in designing the path to achieve SDGs [56].

Build an inclusive political commitment and strong leadership for SDGs at the highest political level. The institutionalization process is an important political guarantee to foster whole government approaches to the SDGs. The continuous improvement and necessary adaptation of legislation to the SDGs framework are achieved through the adoption of an integrated approach of the legislative process (planning, drafting, implementation, evaluation) at all stages [57]. For example, the national SDGs of Austria are set down in the Federal Constitutional Act on animal protection, comprehensive environmental protection, water, and food security [35]. Moreover, the working mechanism for the SDGs nationalization process began with the creation of various specialized agencies in several countries 
(Japan, Afghanistan, Canada, etc.). Pakistan's Parliament became the first to establish an SDG Unit dedicated solely to the 17 goals [51]. Meanwhile, some countries, such as Turkey and Ethiopia, use their well-established mechanisms for implementing the goals at the national level. Enhancing and institutionalizing performance-based monitoring and strengthening accountability mechanisms for civil servants are also important measures. For example, SDGs have been mainstreamed in performance contracting guidelines as a weighted area in the performance matrix in Kenya [58].

Incorporate the SDGs into national development frameworks. The 2030 Agenda stated that when implementing SDGs, it is necessary to consider the reality, capacity, and level of development of a specific country, and respect the country's development strategy and priority projects. Most countries are in the process of the "nationalization" of international policies, integrating the 2030 Agenda with national strategies and plans, and integrating the economic, social, and environmental dimensions in a balanced manner. For example, the "Europe 2020 Strategy" basically covers all the SDGs [27]. About 79.9\% of the SDGs are reflected in the documents of the national planning system in Kazakhstan [59]. Approximately 86\% of the SDGs have the same attributes as Brazil's 2016-2019 Plano Plurianual (PPA) [40]. About 74\% of the SDGs are included in the South African National Development Plan coverage [60]. Meanwhile, the implementation of SDGs and integration of the three dimensions relies on strategic documents, such as the "National Poverty Reduction Strategy 2019-2023" and the "National Energy and Climate Comprehensive Plan 2021-2030" in Spain [61] and the "Norwegian Biodiversity Action Plan" in Norway [62]. Romania also published the "Sustainable Development Strategy 2030" [63], and India's NITI Aayog incorporates the SDGs into central ministries, centrally funded programs, and major government initiatives [43].

Establish national SDGs and indicator systems. Some countries have modified or created a set of national indicators, according to their national conditions, based on the UN SDGs, while other countries have directly adopted the UN indicators for assessment work [64]. Different countries have formulated diverse priorities, which may not always be within the scope of 17 goals. For example, landlocked countries (e.g., Kazakhstan, Armenia, Bhutan) generally did not take effective measures against Life below Water (Goal 14). Lao PDR formally launched and adopted its own national Goal 18 called, "Lives safe from unexploded ordnance" [55]. Afghanistan reclassified the SDGs into 125 national goals and 190 national targets applicable to Afghanistan [50]. Germany has added 13 new areas and 30 indicators following the 2030 Agenda [65]. Austria has set digitalization as a priority, and digital transformation is also being used as a means to implement the 2030 Agenda [35]. Canada has made reconciliation with indigenous people and the renewal of nation-to-nation relationships a priority [33].

Build a national monitoring and evaluation framework for SDGs. Many countries have described how to establish monitoring and evaluation systems at the national level (e.g., Canada, Mexico). The statistical agencies of most countries have undertaken this task (Turkey, Russia, Thailand, etc.). The integrated assessment tool of the United Nations is widely used to assess the level of integration of the SDGs and targets into the documents of the national planning system. New institutions in some countries are responsible for such data collection and policy evaluation. For example, Bangladesh established the "National Data Coordination Committee (NDCC)" to identify data gaps and ensure the availability of high-quality data [53]. Thailand established the "Sub-Committee on Developing Information System" to support the decision making and policy design of the Sustainable Development Committee and relevant agencies [56]. Moreover, some countries, such as Finland and Romania, have established a sustainable development expert group. Some countries tend to use existing agencies to monitor and evaluate the progress of the goals. For example, Israel stated that it would not establish a new special supervision agency [66] and Sweden will assign this work to the responsible persons of relevant ministries [30]. 
Enable extensive participation and negotiation mechanisms. The 2030 Agenda puts forward higher requirements for the coordination of policies and actions among global, regional, and national administrative agencies. From the establishment of inter-ministerial coordination to broader social and public participation in the implementation of the agenda, extensive participation and consultation mechanisms have been adopted in most counties. Many countries believe that the institutional framework plays a vital role in promoting sustainable development, and have established horizontal coordination mechanisms among departments (e.g., Saudi Arabia, Greece, and Mauritius). For example, the Coordination Board on SDGs was established in Kazakhstan [59]. Nonetheless, the negotiation mechanism between national-level institutions and local-level institutions is relatively lacking. For example, not all cities link their work explicitly with the 2030 Agenda in Finland [67]. Before formulating sustainable development policies and submitting VNR, governments of most countries engage in dialogues with stakeholders and other relevant parties, which include civil society, international organizations, the private sector, independent experts, etc. These dialogues often improve the quality of government actions and increase public acceptance of decisions. For example, 17 SDGs were distributed among public and private sectors, NGOs, and local administrations to ensure a wide range of stakeholders' contributions in Turkey [49]. Germany plans to hold 2-3 regular dialogue forums every year [36].

Strengthen the publicity of the SDGs. Most countries attach great importance to raising public awareness and enhancing public participation in the SDGs, which actively promotes the universalization process of the SDGs. For example, Brazil has established several public participation platforms such as the 2030 Agenda platform, dialogue with Brazil, etc. [40]. The Norwegian Ministry of Education recommends including SDGs in school curricula and disseminating knowledge about SDGs [34]. In addition, many countries also pay attention to youth education and participation in the SDGs (e.g., Japan, Denmark, Austria, Finland, and Mauritius), as well as promoting increased awareness of, commitment to, and ownership of the agenda among youth organizations and young people. For example, Japan educates the next generation of youth on sustainable development and rewards schools, families, communities, and units that have been trained on sustainable development knowledge [68].

Provide reliable data and measurable indicators at the national and regional levels. Data collection and statistical work are common problems for all countries [23], which limits progress in setting and assessing interlinkages between targets and policy evaluation. Countries, especially the LDCs in South Asia and Africa, may need support from the United Nations system to improve their data collection capabilities and the ability to evolve or adapt to abrupt challenges (e.g., the COVID-19 pandemic) and long-lasting change (e.g., climatic shifts) $[69,70]$. Thereafter, evidence- and science-based approaches can be developed and applied for indicator-based assessments, benchmarking, integrated approaches, and system analysis and modeling in time and space to support policy implementation and sustainable development at multiple scales in different contexts [71].

\subsubsection{Variances in Policy Implementation across Countries}

Priorities and focus areas are different. LDCs pay more attention to indicators in terms of reducing vulnerability, enhancing resilience, and responding to urgent needs (e.g., Pakistan) [51]. However, OECD countries pay more attention to global environmental issues, and further strengthen and improve the level of welfare based on the already achieved goals (e.g., the UK and Italy). For example, sustainable natural resource management and climate change mitigation and adaptation are priority areas for Norway [34]. Switzerland faces the challenge of reducing the negative impact of domestic consumption on people and the environment in other countries [37]. The Ethiopian government has identified 10 national priority development areas, which are mainly focused on economic development and urban construction [52], in its Second Five Year Growth and Transformation Plan. The 
focus areas of Tajikistan's development for the next 15 years are energy, transportation, food, and employment [72].

Governance and management systems are divergent. Some countries have taken top-down and step-by-step transmission measures in which their central coordination agencies are very important to the implementation processes (e.g., China, India, and Russia). For example, China has established an inter-ministerial coordination mechanism for the implementation of the 2030 Agenda, forming a level of "central-local-basic" implementation mechanisms [38]. In decentralized countries, local governments have greater powers, and the SDGs are mainly implemented through local government plans and urban development plans (e.g., America, Pakistan, and Norway). For example, the "Nature Model" is being developed for the District level in Bangladesh and a framework is being finalized for localizing SDGs at the subdistrict level [53]. Overall, the goals' achievement ultimately depends on the ability of local and national governments to promote integrated, inclusive, and sustainable development.

The Matthew effect seems demonstrated in the implementation of the SDGs. Based on the Sustainable Development Report 2020 [73], the lower the income level of the country, the less progress (on track, maintaining, or increasing) on the implementation of SDG targets. The gap in policy action is a general trend across countries all over the world. OECD countries have a higher enthusiasm and initiative for implementing the SDGs. On the other hand, LDCs have a relatively regressive execution power due to factors such as lack of financial funds and political turmoil. For example, the 2030 Agenda is already at the heart of Spain's government action and is a priority across Spain's political spectrum [61]. Sweden is committed to becoming a leader in implementing the 2030 Agenda-both at home and by contributing to its global implementation [30]. Liberia recognizes that fiscal space is limited, and institutional knowledge and knowledge retention on the related policies and strategies are weak areas [69]. Political turmoil remains in countries such as Myanmar and Kyrgyzstan, which would affect the continuous implementation of the SDGs. Thus, the Matthew effect shall be taken into account to fully achieve SDGs worldwide.

Regional cooperation led by developed and emerging countries sets up global partnerships. OECD or emerging countries make full use of their existing foreign aid policies or regional alliances to further strengthen global or regional cooperation (e.g., US, Britain, India, China, and South Africa). For example, Nordic Countries aim to improve the visibility of the Nordic Council of Ministers' work both in the Nordic Region and internationally [67]. India strengthens South-South Cooperation through financing to its African partners and launching the Indian Technical and Economic Cooperation program across the developing world [43]. Regional organizations (EU, ASEAN, G20, etc.) have formulated their sustainable development strategy or action plan to strengthen internal connections and cohesiveness to improve the regional voice. For example, EU countries emphasize the development of partnerships and assess and predict the relative position of countries in achieving SDGs in the international framework [74,75]. G20 members contribute to the implementation of the 2030 Agenda by taking bold transformative steps through both collective and individual concrete actions at international and domestic levels [76].

The impact of COVID-19 varies. LDCs are extremely vulnerable to the impact of COVID-19 and have compounded all aspects of socioeconomic development [77]. They are unlikely to receive more international assistance soon and face a greater financial burden (e.g., Kenya, Liberia, Nepal, and Afghanistan) [78]. For example, the likelihood of Liberia being able to meet the SDGs seem relatively low, especially given the challenges posed by the COVID-19 outbreak and the projected decline in foreign aid assistance that will result from the pandemic [69]. OECD countries and BRICS countries are affected by COVID-19 and pay more attention to relevant goals of economic and social development in the short term. For example, Finland plans to invest in employment actions, promote the circular economy, perform social and healthcare reformation, increase productivity, and limit expenditure growth under the impact of COVID-19 [67]. Russia approved the Plan of 
High- Priority Measures (Actions) to ensure the sustainable development of the economy in the context of the deterioration of the situation due to COVID-19 [41].

\subsubsection{The Progress of SDGs under the Policy Implementation}

According to the Sustainable Development Report 2020 [73], we mapped the implementation of SDGs (Figure 3) while comparing the progress and changes over different regions and representative countries (Figure 4). The SDG Index tracks country performance on the 17 SDGs with equal weight to all 17 goals. The score signifies a country's position between the worst (0) and the best or target (100) outcomes. All underlying data are made available publicly on www.sdgindex.org (accessed on 25 May 2021). From a spatial perspective, the SDG Index is relatively low in sub-Saharan Africa, South Asia, and Southeast Asia, which are the concentrated areas of LDCs. Among them, Sub-Saharan Africa countries show an absolute low value of the SDG Index, and it is difficult for them to realize the SDGs. In contrast, the SDG Index is relatively high in North America and Western Europe, which consist mostly of OECD countries. Among them, the Nordic Council countries and Canada show an absolute high value of the SDG Index, but they still face the problems of climate change and sustainable use of energy. BRICS countries have a middle value, while China has a relatively high value in comparison.

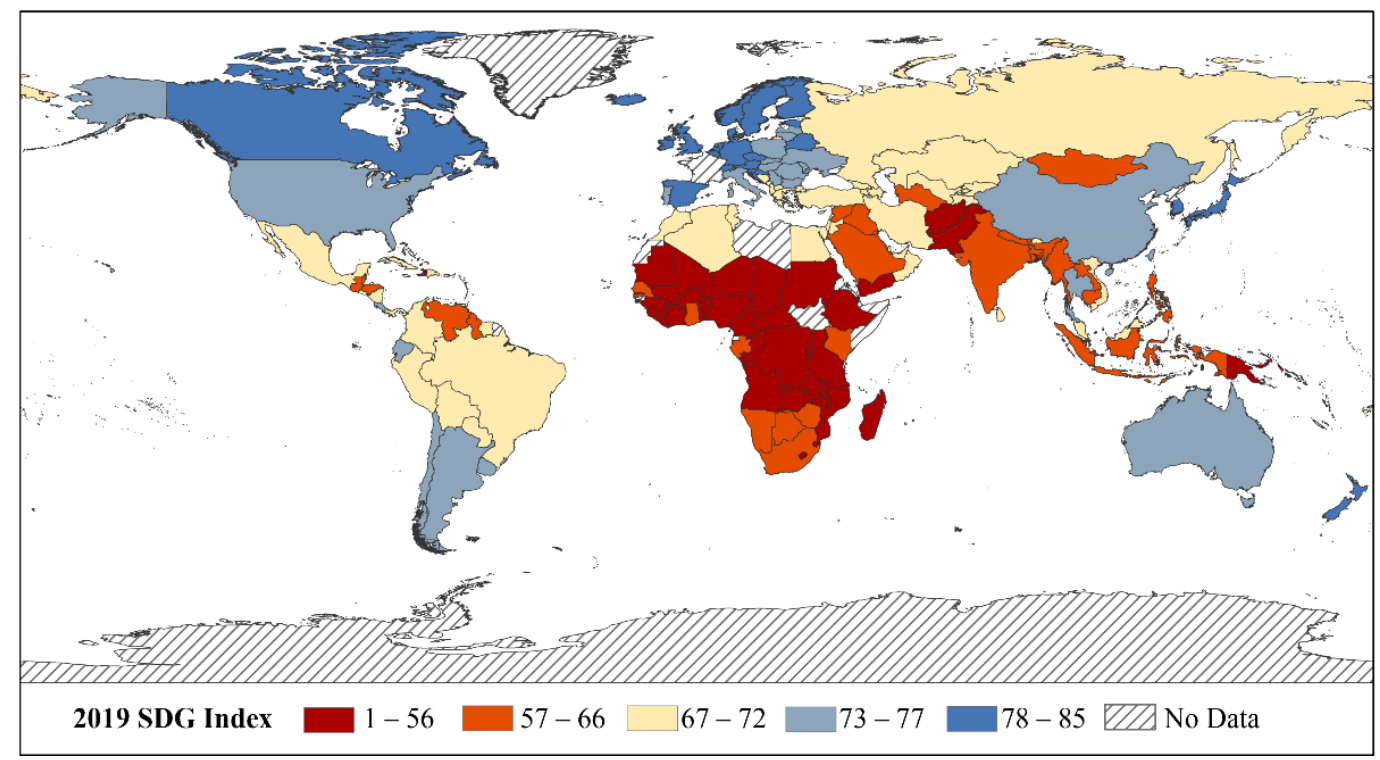

Figure 3. The SDG Index across countries, 2019 (the data derived from the Sustainable Development Report 2020 [73]).

Most countries have made great progress in achieving the SDGs with regard to the policy implementation for No Poverty (Goal 1), Affordable and Clean Energy (Goal 7), Decent Work and Economic Growth (Goal 8), and Climate Action (Goal 13), which has improved the living environment and energy availability for human existence. Asian countries are progressing in No Poverty (Goal 1) and Decent Work and Economic Growth (Goal 8). Sub-Saharan Africa and Oceania are on track in Climate Action (Goal 13). However, Quality Education (Goal 4), Life on Land (Goal 15), and Partnerships (Goal 17) have progressed slowly or even receded. For example, Oceania's progress in Quality Education (Goal 4), Life on Land (Goal 15), and Partnerships (Goal 17) is decreasing, so is Bangladesh's progress in Life on Land (Goal 15) and Partnerships (Goal 17).

Some goals have been achieved ahead of schedule in some countries. For example, Norway is leading in achieving SDGs in terms of No Poverty (Goal 1), Good Health and Well-being (Goal 3), Gender Equality (Goal 5), Affordable and Clean Energy (Goal 7), Reduced Inequalities (Goal 10), and Partnerships (Goal 17). OECD countries and high-income countries have achieved No Poverty (Goal 1), Quality Education (Goal 4), and Industry, Innovation, and Infrastructure (Goal 9) for basic human living. Ethiopia, Sierra Leone, 
and Bangladesh have achieved or gained large progress in Sustainable Consumption and Production (Goal 12) and Climate Action (Goal 13) probably due to their natural ecological conditions and primitive economic production methods. Nevertheless, most countries are still in the initial stage of implementing the SDGs, facing challenges in achieving Zero Hunger (Goal 2), Good Health and Well-being (Goal 3), Reduced Inequalities (Goal 10), and Peace, Justice, and Strong Institutions (Goal 16) for high-quality life and national governance. It seems more difficult for low-income countries to achieve Goals 1-11 and Peace, Justice, and Strong Institutions (Goal 16). Meanwhile, high-income countries face major challenges in Sustainable Consumption and Production (Goal 12) and Climate Action (Goal 13). OECD countries such as the United States still have difficulty in achieving Zero Hunger (Goal 2), Reduced Inequalities (Goal 10), Sustainable Consumption and Production (Goal 12), and Climate Action (Goal 13). China faces major challenges in Reduced Inequalities (Goal 10), Life below Water (Goal 14), and Global Partnerships (Goal 17).

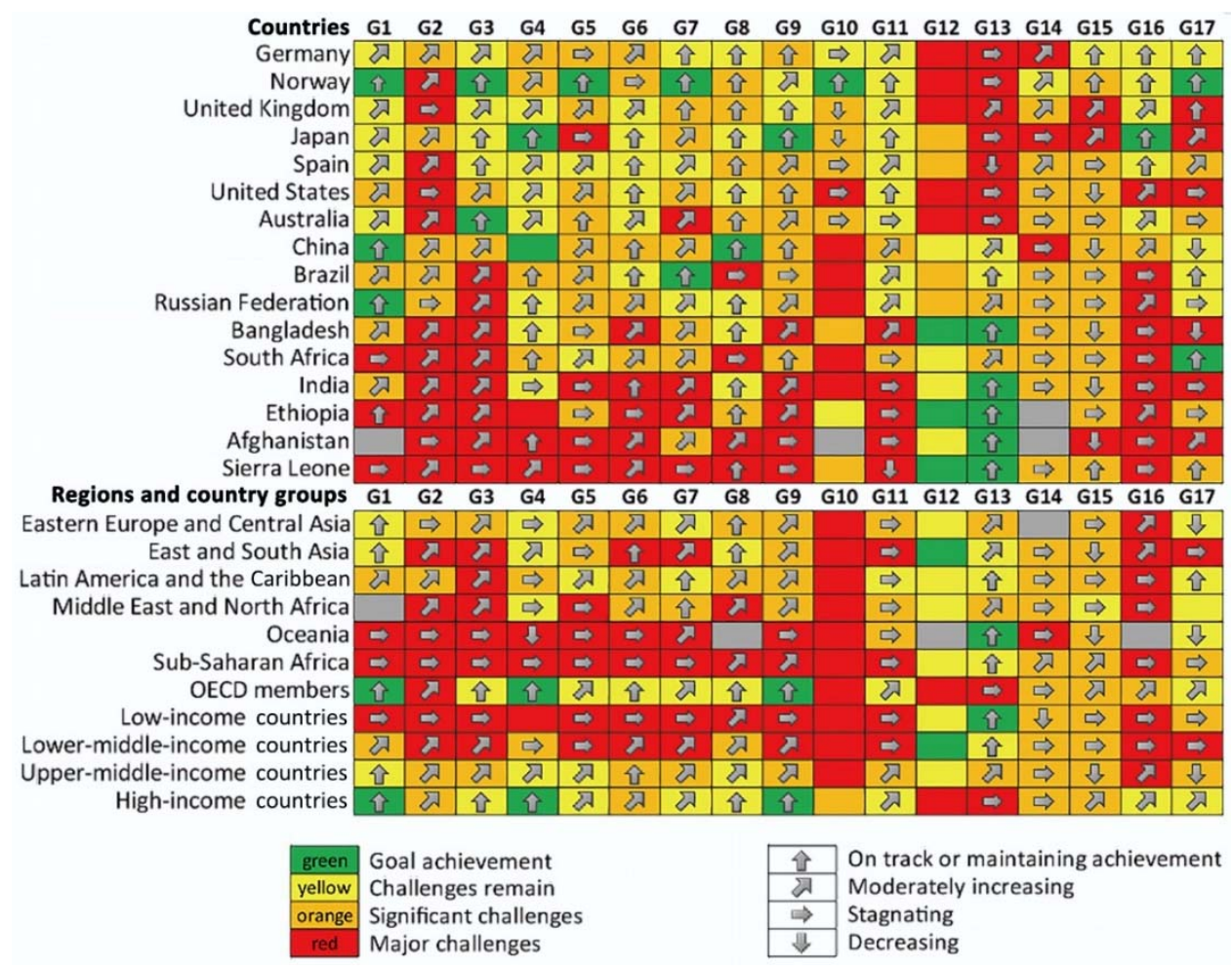

Figure 4. Progress in the implementation of SDGs across representative countries and regions (the data derived from the Sustainable Development Report 2020 [73]).

\section{Implementation of the SDGs in a Post-Pandemic Era}

The COVID-19 outbreak is a major setback to the world's ability to achieve the SDGs, particularly for poor countries and vulnerable groups [23]. Likely, many of the 169 targets will not be achieved by 2030. The United Nations has confirmed an unwelcome suspicion: the COVID-19 has put the SDGs out of reach. Most of the goals, such as end poverty, protect the environment, and support well-being by 2030, were already off course. Now, what little progress had been made has been stopped in its tracks [79]. An estimated 71 million people are expected to be pushed back into extreme poverty in 2020 [23]. If not properly addressed through policy, the social crisis created by the COVID-19 pandemic may also increase inequality, exclusion, discrimination, and global unemployment in the medium and long term [80]. Meanwhile, some experts believe that the COVID-19 may help spur efforts to realize the UN's 2030 Agenda [81], and there might also be some positive developments in the long term [82]. Ambition to achieve the goals is as important as ever, but the pandemic has required countries to revise their strategies for achieving them. We have to discuss whether the SDGs are deserved to be revised or whether the time point to 
achieve them needs to be delayed. We should increase the resilience of the goals and set different priorities for different countries.

As COVID-19 batters the world and its economy, it's time to rethink sustainable pathways for the future of human beings. The COVID-19 has irreparably altered at least some of the SDGs' underpinning assumptions-sustained economic growth and globalization. Some scholars believe that it is unlikely there will be enough money or attention to banish poverty and inequality, expand health services and overturn biodiversity loss and climate change, all by $2030[16,77]$. Therefore, we may adjust the path and focus of the next phase of the SDGs' implementation in a post-pandemic era. We suggest five key points to take into account (Figure 5): integrate SDGs and maximize synergies between goals; set priorities for achieving short- and long-term goals; strengthen global cooperation; assess and predict the progress of the SDGs timely; promote the integration of science, technology, policy and practice (STPP).

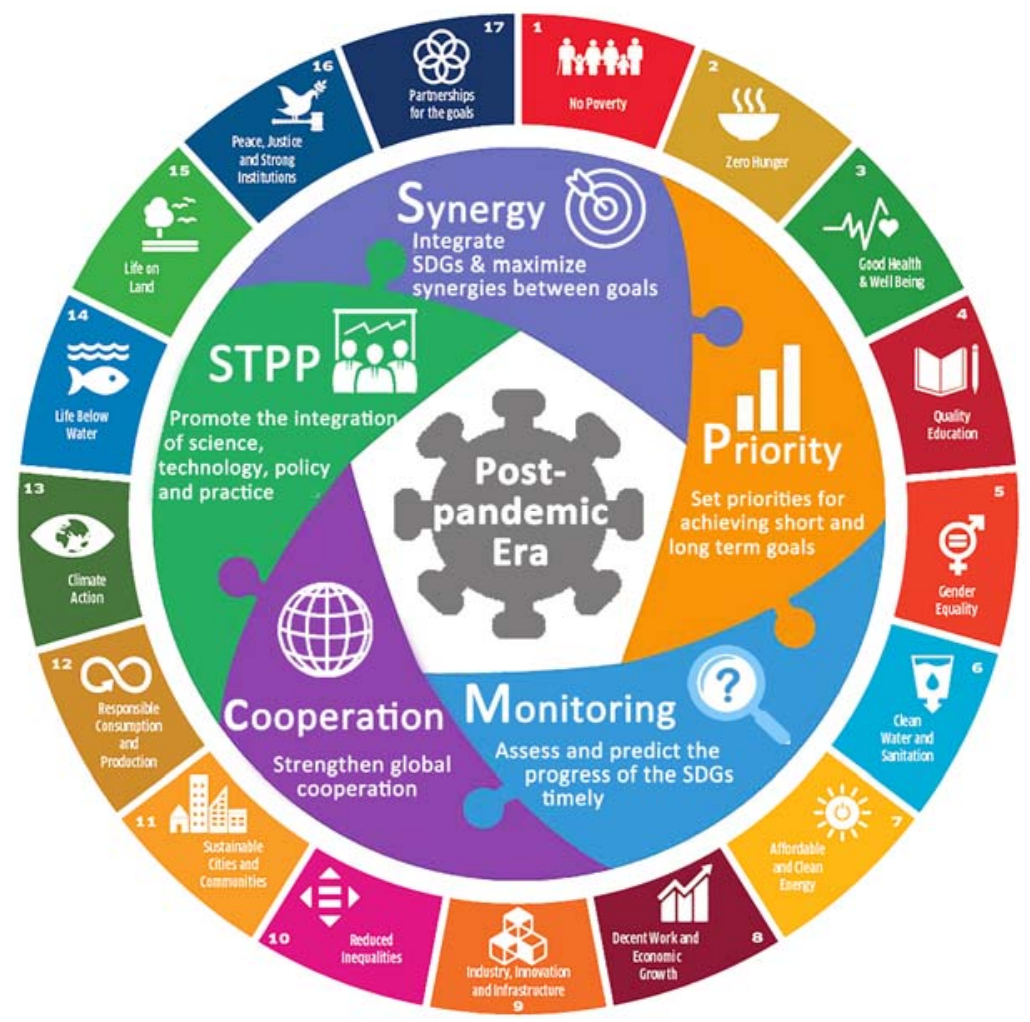

Figure 5. Five key points to implement the SDGs in a post-pandemic era.

\subsection{Integrating SDGs and Maximize Synergies between Goals}

The 17 goals are interrelated, with both negative ("trade-offs") and positive ("cobenefits") $[83,84]$. The economic, social, and environmental targets in the SDGs are entwined as an "indivisible whole." Understanding how goals influence one another (positively or negatively) and finding the leverage points for sustainability transformations are critical to prioritize and implement policies that maximize synergies between goals while navigating trade-offs $[85,86]$. Implementing the SDGs requires cross-sectoral processes and systems thinking to foster policy coherence [87]. Some scholars believe that the existing mode of achieving SDGs is at the cost of environmental degradation [88]. The coupling between humans and nature needs to be addressed in most goals [89,90]. For example, combating climate change can reinforce all 17 goals but may undermine efforts to achieve Sustainable Consumption and Production (Goal 12) [91], the trade-off between emission deceleration and economic growth in China [92]. Using coal to improve energy access Affordable and Clean Energy (Goal 7) in Asian countries, for example, would accelerate climate change and acidify the oceans (undermining Climate Action (Goal 13) and Life 
below Water (Goal 14)), as well as exacerbate other problems, such as health damage from air pollution (i.e., Good Health and Well-being (Goal 3)) [93].

Focusing on a smaller, more integrated set of goals may help reduce the cases in which the implementation of one of the SDGs would impede another. Integrating SDGs is an important move in a post-pandemic era. Even before the COVID-19 pandemic, ideas were floating around about ways to make the goals more achievable, with around five or six targets for each goal [94]. Under one proposal from a group of UN science advisers, the SDGs would be redistributed into six "entry points." These are human well-being (including eliminating poverty and improving health and education), sustainable economies (including reducing inequality), access to food and nutrition, access to and decarbonizing energy, urban development, and the global commons (combining biodiversity and climate change) [95]. The Sustainable Development Solutions Network (SDSN), a related proposal from a different group of advisers, also redistributes the 17 goals into 6, which it calls "transformations." These are education, gender, and inequality; health, well-being, and demography; energy decarburization and sustainable industry; sustainable food, land, water, and oceans; sustainable cities and communities; a digital revolution for sustainable development $[79,96]$. Some scholars use one key goal to integrate other goals. As production dynamics in every country are highly affected by the pandemic, industrial policy is considered part of the response to solve dramatic economic and social problems derived from extraordinary levels of unemployment, deprivation, and poverty [97]. The sustainability of water cannot be simply considered in terms of supply as it has other environmental dimensions, such as the depletion of the groundwater table, drainage problems, and the pollution of surface water bodies [98]. Focusing on poverty alleviation and reducing inequalities will have compound positive effects on all SDGs [99].

The attainment of the 2030 Agenda will greatly depend on whether the identified synergies among the goals can be leveraged in a post-pandemic era [100,101]. Actions initiated to fulfill individual goals should be coherent across efforts to achieve the full set of the SDGs in the long run [102]. For example, the mitigation strategies for climate change and water and air pollution in the post-COVID-19 era may be integrated [103]. The synergies between the SDGs for urban development, food security, and poverty alleviation in rapidly changing peri-urban areas should be taken into account [104]. The co-benefits of nature's contribution to Clean Water and Sanitation (Goal 6), the protection of forest cover (for SDG target 15.2), carbon storage (Climate Action (Goal 13)) and biodiversity (for SDG target 15.5), should be sustainably managed, given the trade-offs with Zero Hunger (Goal 2) [105].

\subsection{Set Priorities for Achieving Short- and Long-Term Goals}

For sustainable development, coping with the trade-offs of short and long-term outcomes is demanding in a post-pandemic era [106]. Some scholars suggested creating some kind of an addition to the SDGs in the form of a protocol clarifying urgent necessities and priorities during a pandemic and recession [107]. COVID-19 has had a major impact on food availability, equity in health services and education, international cooperation, and other goals [23]. A big challenge of the pandemic is how to balance economic and social activities with epidemic prevention and control. In this regard, we should learn more from China's experience. In 2020, China's GDP grew by $2.3 \%$ in real terms, making it the only major economy in the world to achieve positive economic growth, and meanwhile, the pandemic has been effectively controlled. At the same time, the impact of the pandemic presents an opportunity to advance SDGs related to communicable diseases. Some issues became more urgent during the pandemic. For example, 30 of the targets $(18 \%)$ will help reduce the likelihood of another global pandemic. Reducing trafficking in wildlife and the supply and demand of illegal wildlife products will reduce the likelihood of new viruses being transmitted to humans. Three further goals-achieving universal health coverage, strengthening the health workforce, and enhancing the capacity of the global health risk early warning system will mitigate the knock-on effects of the pandemic in low-income countries. Due to COVID-19, the problems in the cities, which recorded $90 \%$ of the re- 
ported cases, have also become more pressing as urban areas house highly diverse people with differing vulnerabilities [108]. Nearly one-quarter of the world's urban population lives in slums, and the inadequate state of public services in these areas requires urgent attention [109].

In the post-pandemic era, the world may take a holistic and all-encompassing approach with a focus on the overall achievement of SDGs while reformulating the short-term and mid-term policies [110]. We refer to the literature $[16,23,73,77]$ and summarize the impacts of COVID-19 on SDGs, implementation priority, and examples of targets impacted by the pandemic (Table 2). In this summary, we identified eight goals that should be prioritized in the short term, including poverty, hunger, health, education, and inequalities. These short-term issues are put forward referring to the highly negative impacts of COVID-19 on the SDGs [73]. For the goals with mild and moderate impacts, we set the implementation priority by medium-term and long-term, such as biodiversity protection, climate action, and affordable and clean energy [12,111].

Table 2. Impacts of the COVID-19 on SDGs and the implementation priority $[16,23,73,77]$.

\begin{tabular}{|c|c|c|c|}
\hline SDGs & Impacts of the COVID-19 on SDGs & $\begin{array}{l}\text { Implementation } \\
\text { Priority }\end{array}$ & Example of Targets \\
\hline Goal 1: No poverty & $\begin{array}{l}\text { - Increased poverty due to job losses } \\
\text { and economic lockdown } \\
\text { - } \quad \text { Disproportionate impact on } \\
\text { vulnerable groups (e.g., the poor) }\end{array}$ & Short-term & $\begin{array}{c}\text { Target 1.1: eradicate extreme } \\
\text { poverty } \\
\text { Target 1.4: provide equal access to } \\
\text { basic services }\end{array}$ \\
\hline Goal 2: Zero hunger & $\begin{array}{l}\text { Food insecurity due to reduction in } \\
\text { global food supplies and trade } \\
\text { Hunger due to fall in incomes and } \\
\text { reduced food availability during } \\
\text { lockdown }\end{array}$ & Short-term & $\begin{array}{c}\text { Target 2.1: end hunger and ensure } \\
\text { access to safe, nutritious, and } \\
\text { sufficient food }\end{array}$ \\
\hline $\begin{array}{l}\text { Goal 3: Good health } \\
\text { and well-being }\end{array}$ & $\begin{array}{l}\text { Higher mortality from other causes } \\
\text { because of overburdening of health } \\
\text { systems } \\
\text { - } \quad \begin{array}{l}\text { Interrupt childhood immunization } \\
\text { efforts globally }\end{array} \\
\text { - Negative impact of confinement } \\
\text { and lockdown on mental health }\end{array}$ & Short-term & $\begin{array}{l}\text { Target 3.4: reduce by one-third } \\
\text { premature mortality, promote } \\
\text { mental health and well-being } \\
\text { Target 3.8: achieve universal } \\
\text { health coverage }\end{array}$ \\
\hline $\begin{array}{l}\text { Goal 4: Quality } \\
\text { education }\end{array}$ & $\begin{array}{l}\text { - School and day-care closures } \\
\text { Loss in the development of human } \\
\text { capital } \\
\text { Educational inequality increases } \\
\text { due to the lack of remote learning } \\
\text { facilities }\end{array}$ & Short-term & $\begin{array}{l}\text { Target 4.1: provide free, equitable, } \\
\text { and quality education for all } \\
\text { children } \\
\text { Target 4.7: ensure that all learners } \\
\text { acquire the knowledge and skills }\end{array}$ \\
\hline $\begin{array}{l}\text { Goal 5: Gender } \\
\text { equality }\end{array}$ & $\begin{array}{l}\text { - Possible disproportionate economic } \\
\text { impacts on women (e.g., job losses, } \\
\text { poverty) } \\
\text { Intensify the risk of violence against } \\
\text { women and girls from the lockdown }\end{array}$ & $\begin{array}{l}\text { Medium-term and } \\
\text { long-term }\end{array}$ & $\begin{array}{l}\text { Target 5.4: value unpaid care and } \\
\text { domestic work by providing } \\
\text { public services and policies }\end{array}$ \\
\hline
\end{tabular}


Table 2. Cont.

\begin{tabular}{|c|c|c|c|}
\hline SDGs & Impacts of the COVID-19 on SDGs & $\begin{array}{l}\text { Implementation } \\
\text { Priority }\end{array}$ & Example of Targets \\
\hline $\begin{array}{l}\text { Goal 6: Clean water } \\
\text { and sanitation }\end{array}$ & $\begin{array}{l}\text { Limited access to clean water } \\
\text { among disadvantaged groups }\end{array}$ & $\begin{array}{l}\text { Medium-term and } \\
\text { long-term }\end{array}$ & $\begin{array}{l}\text { Target 6.1: give access to safe and } \\
\text { affordable drinking water for all }\end{array}$ \\
\hline $\begin{array}{l}\text { Goal 7: Affordable } \\
\text { and clean energy }\end{array}$ & $\begin{array}{l}\text { - Slowdown in economic growth } \\
\text { contributing to a reduction in } \\
\text { energy prices (e.g., oil), which might } \\
\text { increase access to energy but reduce } \\
\text { incentives for renewables }\end{array}$ & $\begin{array}{l}\text { Medium-term and } \\
\text { long-term }\end{array}$ & $\begin{array}{l}\text { Target 7.2: increase substantially } \\
\text { the share of renewable energy }\end{array}$ \\
\hline $\begin{array}{l}\text { Goal 8: Decent work } \\
\text { and economic } \\
\text { growth }\end{array}$ & $\begin{array}{l}\text { Economic crisis in virtually all parts } \\
\text { of the world } \\
\text { Trade disruption; Business } \\
\text { closures/bankruptcies; Mass } \\
\text { unemployment } \\
\text { - } \quad \text { Sharp decline in tourism activities } \\
\text { - Massive public deficits }\end{array}$ & Short-term & $\begin{array}{l}\text { Target 8.1: sustain per capita } \\
\text { economic growth } \\
\text { Target 8.5: achieve full and } \\
\text { productive employment and } \\
\text { decent work } \\
\text { Target 8.9: promote sustainable } \\
\text { tourism that creates jobs }\end{array}$ \\
\hline $\begin{array}{l}\text { Goal 9: Industry, } \\
\text { innovation, and } \\
\text { infrastructure }\end{array}$ & $\begin{array}{l}\text { - } \quad \text { Decline in industrial outputs } \\
\text { Aviation industry and } \\
\text { manufacturing has likely suffered } \\
\text { the steepest decline and possible } \\
\text { nationalization of some industries }\end{array}$ & $\begin{array}{l}\text { Medium-term and } \\
\text { long-term }\end{array}$ & $\begin{array}{c}\text { Target 9.3: increase the access of } \\
\text { small-scale industrial to financial } \\
\text { services }\end{array}$ \\
\hline $\begin{array}{l}\text { Goal 10: Reduced } \\
\text { inequalities }\end{array}$ & $\begin{array}{l}\text { Disproportionate negative health } \\
\text { and economic impacts on } \\
\text { vulnerable groups (including } \\
\text { refugees and migrants), especially } \\
\text { in countries with low safety nets } \\
\text { Loss of jobs of lower-skilled, } \\
\text { lower-wage labor }\end{array}$ & Short-term & $\begin{array}{l}\text { Target 10.1: sustain above-average } \\
\text { income growth of the bottom } 40 \% \\
\text { of the population } \\
\text { Target 10.7: facilitate orderly, safe, } \\
\text { regular and responsible migration } \\
\text { and mobility of people }\end{array}$ \\
\hline $\begin{array}{l}\text { Goal 11: Sustainable } \\
\text { cities and } \\
\text { communities }\end{array}$ & $\begin{array}{l}\text { - } \quad \text { Rise in urban poverty and } \\
\text { vulnerability } \\
\text { - } \quad \text { Shut down of public transports } \\
\text { Lower access to public/green } \\
\text { spaces } \\
\text { Movements of the population that } \\
\text { vary across countries }\end{array}$ & Short-term & $\begin{array}{l}\text { Target 11.2: give access to safe, } \\
\text { affordable, and sustainable } \\
\text { transport systems for all } \\
\text { Target 11.7: provide universal } \\
\text { access to safe, inclusive, and } \\
\text { accessible, green and public } \\
\text { spaces }\end{array}$ \\
\hline $\begin{array}{l}\text { Goal 12: Responsible } \\
\text { consumption and } \\
\text { production }\end{array}$ & $\begin{array}{l}\text { Pressure to loosen up regulations on } \\
\text { circular economy and postpone the } \\
\text { adoption of new measures }\end{array}$ & $\begin{array}{l}\text { Medium-term and } \\
\text { long-term }\end{array}$ & $\begin{array}{l}\text { Target 12.5: reduce waste } \\
\text { generation through prevention, } \\
\text { reduction, recycling, and reuse }\end{array}$ \\
\hline $\begin{array}{l}\text { Goal 13: Climate } \\
\text { action }\end{array}$ & $\begin{array}{l}\text { - Lack of clarity on environmental } \\
\text { investments } \\
\text { Slowdown in economic growth } \\
\text { contributing to a reduction in } \\
\text { energy prices (e.g., oil), which might } \\
\text { increase access to energy but reduce } \\
\text { incentives for renewables }\end{array}$ & Medium- and long-term & $\begin{array}{l}\text { Target 13.A: mobilize US } \$ 100 \\
\text { billion annually by } 2020 \text { for the } \\
\text { Green Climate Fund to address } \\
\text { the needs of developing countries }\end{array}$ \\
\hline
\end{tabular}


Table 2. Cont.

\begin{tabular}{|c|c|c|c|}
\hline SDGs & Impacts of the COVID-19 on SDGs & $\begin{array}{l}\text { Implementation } \\
\text { Priority }\end{array}$ & Example of Targets \\
\hline $\begin{array}{l}\text { Goal 14: Life below } \\
\text { water }\end{array}$ & $\begin{array}{l}\text { Pressure to reduce marine } \\
\text { biodiversity and ecosystem } \\
\text { safeguards }\end{array}$ & Medium- and long-term & $\begin{array}{l}\text { Target 14.1: by } 2025 \text {, prevent } \\
\text { marine pollution of all kinds }\end{array}$ \\
\hline Goal 15: Life on land & $\begin{array}{l}\text { Pressure to reduce terrestrial and } \\
\text { freshwater biodiversity and } \\
\text { ecosystem safeguards, including } \\
\text { biodiversity and ecosystem } \\
\text { regulations conventions }\end{array}$ & Medium- and long-term & $\begin{array}{l}\text { Target 15.4: ensure the } \\
\text { conservation of mountain } \\
\text { ecosystems, including their } \\
\text { biodiversity. }\end{array}$ \\
\hline $\begin{array}{l}\text { Goal 16: Peace, } \\
\text { justice, and strong } \\
\text { institutions }\end{array}$ & $\begin{array}{l}\text { Pressure to increase accessible } \\
\text { health care in countries that have } \\
\text { not yet achieved universal health } \\
\text { coverageIncreased public deficits } \\
\text { and debt }\end{array}$ & Medium- and long-term & $\begin{array}{l}\text { Target 16.10: ensure public access } \\
\text { to information and protect } \\
\text { fundamental freedoms }\end{array}$ \\
\hline $\begin{array}{l}\text { Goal 17: } \\
\text { Partnerships for the } \\
\text { goals }\end{array}$ & $\begin{array}{l}\text { Possible reduced responsiveness of } \\
\text { international aid community to } \\
\text { needs of the poorest countries } \\
\text { - Possible reduction in international } \\
\text { remittances and cross-border } \\
\text { financing } \\
\text { - Closing of borders } \\
\text { - Slowdown in international trade }\end{array}$ & Short-term & $\begin{array}{l}\text { Target 17.2: developed countries } \\
\text { should commit at least } 0.7 \% \text { of } \\
\text { gross national income in overseas } \\
\text { aid for developing and } 0.15 \% \text { to } \\
\text { least-developed nations } \\
\text { Target } 17.3 \text { : mobilize additional } \\
\text { financial resources for developing } \\
\text { countries from multiple sources }\end{array}$ \\
\hline
\end{tabular}

\subsection{Global Cooperation and Multilateralism Remain the Inevitable Choice for SDGs Implementation}

COVID-19 has seriously affected the process of globalization. The current crisis, including hostilities among major powers, raises the specter of global conflict instead of global cooperation [73]. Foreign direct investment and global value chains are likely to take a hit from the COVID-19 crisis [23]. Thus, global cooperation is more urgent than ever in the face of a pandemic, especially with regard to the development and distribution of vaccines, food, and anti-epidemic supplies, providing assistance to least developed countries, regional travel quarantine, and virus mechanism research.

The Sustainable Development Report 2020 identifies five key measures for global cooperation: (1) disseminate best practices rapidly; (2) strengthen financing mechanisms for developing countries; (3) address hunger hotspots; (4) ensure social protection; (5) promote new drugs and vaccines [23]. It is necessary to strengthen financing mechanisms for developing countries, considering that they are severely affected by COVID-19. The IMF needs ample firepower, including far greater latitude to extend credits, either under existing facilities or through a new issuance of Special Drawing Rights (SDRs) [73]. LDCs need global support from the lead United Nations agencies, including the Office for the Coordination of Humanitarian Affairs, the Food and Agriculture Organization, and the World Food Program, so that they can head off impending hunger crises and food insecurity [73]. Moreover, the promotion of new drugs and vaccines is imminent. Financing R\&D for COVID-19 drugs and vaccines is an urgent global public good. Without global cooperation, R\&D will be inadequate and duplicative. There will also be inequality in the distribution of vaccines since many countries cannot afford to make or buy them.

Assessing policy coherence and coordination of sustainable development across countries is essential. Policy Coherence for Development, which is considered a pillar of the 2030 Agenda [112], can link different SDGs when used as a methodology [113]. SDG Target 17.14 calls on all countries to "enhance policy coherence for sustainable development" as 
a key means of implementation. It requires meaningful collaboration and coordinated action across both policy sectors and different levels of government. It also requires balancing short-term priorities with long-term sustainability objectives and taking into account the impact of domestic policies on global well-being outcomes. Coherence between the development policies of recipients and the providers of development assistance [114], cross-jurisdiction policy coherence, and national coordination should be improved [115].

Regional cooperation is very effective to increase mutual support among regional neighbors. From a policy coherence perspective, a wide range of policy instruments is already in place in the EU to foster synergies, which may have co-benefits. The Forum of the Countries of Latin America and the Caribbean on Sustainable Development provides peer learning opportunities, the exchange of good practices, and the discussion of common goals and seeks to encourage cooperation with regional and subregional organizations to guide an inclusive regional process toward sustainable development in Latin America and the Caribbean [116]. The ASEAN-EU Cooperation Initiative was launched to further strengthen policy dialogue, promote economic and trade connectivity, and support the blueprint for an ASEAN Economic Community. The China-EU 2020 Strategic Agenda for Cooperation is a joint effort to lead the way in improving global resource efficiency and implementing the SDGs. In addition, it is suggested that countries explore regional collaboration around specific goals of SDGs, for example, horizontal ecological compensation mechanism between countries based on the economic, energy, and ecological environment.

Strategies to achieve the SDGs need to be implemented domestically without generating negative impacts on other countries ("spillovers"). The spillover effect covers financial spillovers (e.g., financial secrecy, profit shifting), environmental and social impacts embodied into trade and consumption (e.g., imported $\mathrm{CO}_{2}$ emissions, imported biodiversity threats, accidents at work embodied into the trade), and security/development cooperation (Official Development Aid, weapons exports) [73]. The SDGs are to pursue the win-win of all humankind rather than the one-win of a certain country. Such telecoupling and hidden coupling between countries are also what we need to take care of in the future [90].

Global climate change and natural disasters are linked to multiple SDGs, for example, Zero Hunger (Goal 2), Clean Water and Sanitation (Goal 6), Decent Work and Economic Growth (Goal 8), Industry, Innovation, and Infrastructure (Goal 9), Sustainable Cities and Communities (Goal 11), Life below Water (Goal 14), and Life on Land (Goal 15) [117]. Thus, global cooperation under different international frameworks, such as the Sendai Framework, the Paris Agreement, and the 2030 Agenda, should be strengthened through joint seminars of three agreed committees including enterprises and government at various levels [118].

\subsection{Assess and Predict the Progress of the SDGs Timely Based on Big Data}

Many countries and institutions have begun to evaluate the process of the SDGs. However, in the face of such an unpredictable event as COVID-19, we need more timely and effective progress assessments of the SDGs for clear and unambiguous messages to be conveyed to users (decision makers and policymakers and also the lay public) [119] and to help adjust policies on time under the impact of a pandemic. We have made a few suggestions as follows.

First, carry out a rapid assessment or real-time monitoring of different SDGs by taking advantage of big data. This includes remote sensing data, network data, population movement data, etc. Since the SDGs were proposed in 2015, SDSN has built the SDGs Index and publishes the annual SDG Index and Dashboards Report every year to evaluate each country's implementation of the SDGs and to create a favorable environment for using the data revolution to promote sustainable development. At present, the UN carries out annual progress reports on a national basis, but many indicators are difficult to obtain. For example, the statistical caliber of the indicators is different in each country. Cross-country comparisons are poor, and the data at the subnational scale (provincial and state scale) are more difficult to obtain. Big data demonstrated to be a powerful tool for epidemic 
transmission analysis and prevention decision-making support, especially during COVID19 [120]. Timely, quality, open, and disaggregated data are critical in understanding, managing, and mitigating the human, social, and economic effects of COVID-19 [121]. Big Earth data science is worth developing to provide the methodologies and tools of generating knowledge from diverse, numerous, and complex data sources. Doing so is necessary and essential to ensuring a sustainable human society for the preservation of planet Earth [122,123], for example, evaluating clean water and sanitation and life below the water by using earth observation systems [124], and using population movement data to assess cities' health [125].

Second, increased uncertainty risk assessment in future policymaking will enhance regional development resilience. Decision makers who are implementing and tracking the SDGs may employ probabilistic decision analysis, including uncertainty in predictive models [126], which may strengthen government capacities to anticipate and manage unforeseen disruptive events. An increasing understanding of the need to address the root causes of uncertainty risk has led to calls for greater synergistic coherence between the Sendai Framework, the Paris Agreement, and the SDGs $[9,127]$ as well as strengthened cooperation in fragile areas such as coastal zones, arid areas, and urban agglomerations "critical transition zone" (e.g., peri-urban and forest margin areas in the Global South) [128]. Special attention should be paid to telecoupling and lag coupling between man and nature, to facilitate risk assessment and identify the early warnings of climate change, major health events, and natural disasters [90]. Urban resilience is increasingly considered essential to managing the risks and challenges arising in a globally changing, connected, and urbanized world [129]. If cities are built or restructured to realize the SDGs, we will stand a much higher chance of coping more effectively with the next pandemic [130].

\subsection{Promote the Integration of Science, Technology, Policy, and Practice (STPP)}

It is very important to push the boundaries of science, technology, policy, and practice reflection forward, and toward an integrated implementation of the SDGs [131-133]. However, this integration in many countries is difficult; for example, researchers, policymakers, and practitioners have multiple, often conflicting yet poorly documented priorities on how agriculture could or should support achieving the SDGs [134], which have led to disastrous outcomes for public health, the economy, and international collaboration [135]. There is often a serious lack of consideration of the adoption of systems thinking and integrated analytical approaches and models in policymaking [71]. Government should play a major role in advancing the integration of STPP. Researchers in sustainability science and other disciplines could work together to solve problems and strengthen the science-policy-society interface, providing policymakers information they can use to solve development problems by using scenario modeling tools [95,136]. All kinds of emerging technologies (e.g., ICT, renewable energy, biotechnology, artificial intelligence) are having a powerful impact on SDGs, and the government plays an important role in them [137]. Of the 169 SDG targets, 103 are directly influenced by digital technologies [138], which has the potential to open up new employment opportunities for the poor and solve challenges such as the nation's aging workforce and global pollution [139]. Meanwhile, the positive and negative effects of artificial intelligence and the digital economy in achieving the SDGs should be discussed sufficiently $[140,141]$.

Although networks across the boundaries of science-technology-policy-practice are still in their infancy, deeper collaborations and dialogues between scientists, the government, and the public are also quite important [142]. Some scholars identify three key governance challenges that are central for implementing the SDGs: cultivating collective action by creating inclusive decision spaces for stakeholder interaction across multiple sectors and scales; making difficult trade-offs, focusing on equity, justice, and fairness; and ensuring mechanisms exist to hold societal actors to account regarding decision making, investment, action, and outcomes [143]. Balancing the conflicts of interest among different groups and improving SDGs literacy and education to modify social norms and behaviors 
is what we should accomplish in the future [144]. Large-scale comparative data and measurable indicators are hence required in the impact assessment of policy interventions to identify whether policies are working and how to improve [145]. This calls for joint efforts and inputs of multiple stakeholders by combining technocratic and bottom-up knowledge from proactive and conscious individuals and collectives through context- specific social networks [146].

Author Contributions: Conceptualization, H.L. and Y.C.; investigation, Y.C.; writing-original draft preparation, Y.C. and H.L.; writing-review and editing, H.L., S.W., X.C. and Q.L.; visualization, Y.C. and H.L.; project administration, H.L.; funding acquisition, H.L. All authors have read and agreed to the published version of the manuscript.

Funding: The National Natural Science Foundation of China, grant number 41801164; the Institute of Water and Soil Conservation, Chinese Academy of Sciences and Ministry of Water Resources, Grant Number A314021402-2018; the Start-up Research Program of IGSNRR, Chinese Academy of Sciences, Grant Number E0V00102YZ.

Data Availability Statement: Publicly available datasets were analyzed in this study. This data can be found here: www.sdgindex.org (accessed on 25 May 2021).

Conflicts of Interest: The authors declare no conflict of interest.

$\begin{array}{ll}\text { Abbreviations } \\ \text { APEC } & \text { Asia-Pacific Economic Cooperation } \\ \text { ASEAN } & \text { Association of Southeast Asian Nations } \\ \text { ASEM } & \text { Asia-Europe Meeting } \\ \text { BRICS } & \text { Brazil, Russia, India, China, and South Africa } \\ \text { CARICOM } & \text { Caribbean Community } \\ \text { EAEU } & \text { Eurasian Economic Union } \\ \text { G20 } & \text { Group 20 } \\ \text { LDCs } & \text { Less Developed Countries } \\ \text { NDCC } & \text { National Data Coordination Committee } \\ \text { NGO } & \text { Non-Governmental Organization } \\ \text { NITI Aayog } & \text { National Institution for Transforming India } \\ \text { ODA } & \text { Official Development Assistance } \\ \text { OECD } & \text { Organization for Economic Co-operation and Development } \\ \text { PPA } & \text { Plano Plurianual } \\ \text { SCO } & \text { Shanghai Cooperation Organization } \\ \text { SCI } & \text { Science Citation Index } \\ \text { SDGs } & \text { Sustainable Development Goals } \\ \text { SDR } & \text { Sustainable Development Report } \\ \text { SDRs } & \text { Special Drawing Rights } \\ \text { SDSN } & \text { the Sustainable Development Solutions Network } \\ \text { STPP } & \text { Science, technology, policy and practice } \\ \text { SSCI } & \text { Social Sciences Citation Index } \\ \text { UN } & \text { the United Nations } \\ \text { VNR } & \text { Voluntary National Reports } \\ & \end{array}$

\section{References}

1. Stafford-Smith, M.; Griggs, D.; Gaffney, O.; Ullah, F.; Reyers, B.; Kanie, N.; Stigson, B.; Shrivastava, P.; Leach, M.; O’Connell, D. Integration: The key to implementing the sustainable development goals. Sustain. Sci. 2017, 12, 911-919. [CrossRef]

2. Salvia, A.L.; Leal, W.; Brandli, L.L.; Griebeler, J.S. Assessing research trends related to sustainable development goals: Local and global issues. J. Clean. Prod. 2019, 208, 841-849. [CrossRef]

3. Rosati, F.; Faria, L.G. Addressing the SDGs in sustainability reports: The relationship with institutional factors. J. Clean. Prod. 2019, 215, 1312-1326. [CrossRef]

4. Fortunski, B. Sustainable development and energy policy: Actual $\mathrm{CO}_{2}$ emissions in the european union in the years 1997-2017, considering trade with china and the USA. Sustainability 2020, 12, 10. [CrossRef] 
5. Srinivas, R.; Singh, A.P.; Shankar, D. Understanding the threats and challenges concerning ganges river basin for effective policy recommendations towards sustainable development. Environ. Dev. Sustain. 2020, 22, 3655-3690. [CrossRef]

6. Azevedo, S.G.; Sequeira, T.; Santos, M.; Nikuma, D. Climate change and sustainable development: The case of amazonia and policy implications. Environ. Sci. Pollut. Res. 2020, 27, 7745-7756. [CrossRef]

7. Liang, Y.T.; Zhou, Z.K.; Li, X. Dynamic of regional planning and sustainable development in the pearl river delta, china. Sustainability 2019, 11, 17. [CrossRef]

8. Priyadarshini, P.; Abhilash, P.C. Exploring the 'safe operating space' of india for the implementation of un-sustainable development goals through effectual policy alignment. Sustain. Sci. 2020, 15, 1149-1168. [CrossRef]

9. Saunders, W.S.A.; Kelly, S.; Paisley, S.; Clarke, L.B. Progress toward implementing the sendai framework, the paris agreement, and the sustainable development goals: Policy from aotearoa new zealand. Int. J. Disaster Risk Sci. 2020, 11, 190-205. [CrossRef]

10. Dhakal, S.P.; Burgess, J. Decent work for sustainable development inpost-crisisnepal: Social policy challenges and a way forward. Soc. Policy Adm. 2021, 15, 128-142. [CrossRef]

11. Harris, P.; Riley, E.; Dawson, A.; Friel, S.; Lawson, K. "Stop talking around projects and talk about solutions": Positioning health within infrastructure policy to achieve the sustainable development goals. Health Policy 2020, 124, 591-598. [CrossRef]

12. Elavarasan, R.M.; Pugazhendhi, R.; Jamal, T.; Dyduch, J.; Arif, M.T.; Kumar, N.M.; Shafiullah, G.; Chopra, S.S.; Nadarajah, M. Envisioning the UN sustainable development goals (SDGs) through the lens of energy sustainability (SDG 7) in the post-covid-19 world. Appl. Energy 2021, 292, 116665. [CrossRef]

13. Chae, Y.; Choi, S.H.; Kim, Y.J. Climate change policy implications of sustainable development pathways in korea at sub-national scale. Sustainability 2020, 12, 18. [CrossRef]

14. WB. June 2020 Global Economic Prospects; WB: Washington, DC, USA, 2020.

15. Ghebreyesus. Impact of Coronavirus Will Be Felt for Decades to Come. Available online: https://huacheng.gz-cmc.com/pages/ 2020/08/01/506f7a108cc54dadb7aab1b1fc6d1d3b.html (accessed on 1 May 2021).

16. Naidoo, R.; Fisher, B. Reset sustainable development goals for a pandemic world. Nature 2020, 583, 198-201. [CrossRef] [PubMed]

17. Davalos, L.M.; Austin, R.M.; Balisi, M.A.; Begay, R.L.; Hofman, C.A.; Kemp, M.E.; Lund, J.R.; Monroe, C.; Mychajliw, A.M.; Nelson, E.A.; et al. Pandemics' historical role in creating inequality. Science 2020, 368, 1322-1323.

18. Valensisi, G. Covid-19 and global poverty: Are ldcs being left behind? Eur. J. Dev. Res. 2020, 32, 1535-1557. [CrossRef]

19. Laborde, D.; Martin, W.; Swinnen, J.; Vos, R. Covid-19 risks to global food security. Science 2020, 369, 500-502. [CrossRef] [PubMed]

20. Stephens, E.C.; Martin, G.; van Wijk, M.; Timsina, J.; Snow, V. Editorial: Impacts of COVID-19 on agricultural and food systems worldwide and on progress to the sustainable development goals. Agric. Syst. 2020, 183, 102873. [CrossRef] [PubMed]

21. Parikh, P.; Diep, L.; Gupte, J.; Lakhanpaul, M. Covid-19 challenges and wash in informal settlements: Integrated action supported by the sustainable development goals. Cities 2020, 107, 102871. [CrossRef]

22. McCleery, R.A.; Fletcher, R.J.; Kruger, L.M.; Govender, D.; Ferreira, S.M. Conservation needs a covid-19 bailout. Science 2020, 369 , 515-516.

23. United Nations. The Sustainable Development Goals Report 2020; UN: New York, NY, USA, 2020.

24. Von Stechow, C.; Minx, J.C.; Riahi, K.; Jewell, J.; McCollum, D.L.; Callaghan, M.W.; Bertram, C.; Luderer, G.; Baiocchi, G. 2 degrees c and SDGs: United they stand, divided they fall? Environ. Res. Lett. 2016, 11, 034022. [CrossRef]

25. Rayman-Bacchus, L.; Radavoi, C.N. Advancing culture's role in sustainable development: Social change through cultural policy. Int. J. Cult. Policy 2020, 26, 649-667. [CrossRef]

26. United Nations. Transforming Our World: The 2030 Agenda for Sustainable Development. Available online: https:// sustainabledevelopment.un.org (accessed on 1 May 2021).

27. European Commission. Sustainable Development: EU Sets out Its Priorities; EU: Strasbourg, France, 2016.

28. Government UK. Agenda 2030:The UK Government's Approach to Delivering the Global Goals for Sustainable Development-At Home and Around the World; Government UK: London, UK, 2017.

29. Boto-Alvarez, A.; Garcia-Fernandez, R. Implementation of the 2030 agenda sustainable development goals in spain. Sustainability 2020, 12, 2546. [CrossRef]

30. Government Sweden. Sweden and the 2030 Agenda: Report to the UN High Level Political Forum 2017 on Sustainable Development; Government Sweden: Stockholm, Sweden, 2017.

31. Government UK. Voluntary National Review of Progress towards the Sustainable Development Goals of United Kingdom of Great Britain and Northern Ireland; Government UK: London, UK, 2019.

32. Jeffrey, D.S.; Lynch, A.; LoPresti, A.; Fox, C. Sustainable Development Report of the United States 2018; SDG USA and Sustainable Development Solutions Network (SDSN): New York, NY, USA, 2018.

33. Government Canada. Canada's Implementation of the 2030 Agenda for Sustainable Development, Voluntary National Review; Government Canada: Ottawa, ON, Canada, 2018.

34. Government Norway. Initial Steps towards the Implementation of the 2030 Agenda. Voluntary National Review Presented at the High-Level Political Forum on Sustainable Development (hlpf); Government Norway: Oslo, Norway, 2016.

35. Government Austria. Austria and the 2030 Agenda Voluntary National Review-Report on the Implementation of the s Ustainable Development Goals; Government Austria: Vienna, Austria, 2020. 
36. Government Germany. Report of the German Federal Government to the High-Level Political Forum on Sustainable Development 2016; Government Germany: Berlin, Germany, 2016.

37. Government Switzerland. Switzerland Implements the 2030 Agenda for Sustainable Development, Switzerland's Country Report 2018; Government Switzerland: Bern, Switzerland, 2018.

38. Government China. China's National Plan on Implemention of the 2030 Agenda for Sustainable Development; Government China: Beijing, China, 2016.

39. The State Council Information Office of the People's Republic of China. Poverty Alleviation: China's Experience and Contribution; The State Council Information Office of the People's Republic of China: Beijing, China, 2021.

40. Government Brazil. Voluntary National Review on the Sustainable Development Goals; Government Brazil: Brasília, Brazil, 2017.

41. Government Russia Federation. Voluntary National Review of the Progress Made in the Implementation of the 2030 Agenda for Sustainable Development; Analytical Center for the Government of the Russian Federation: Moscow, Russia, 2020.

42. Liu, H.; Fang, C.; Miao, Y.; Ma, H.; Zhang, Q.; Zhou, Q. Spatio-temporal evolution of population and urbanization in the countries along the belt and road 1950-2050. J. Geogr. Sci. 2018, 28, 919-936. [CrossRef]

43. Government India. India vnr 2020: Decade of Action Taking SDGs from Global to Local; NITI Aayog, Government of India: New Delhi, India, 2020.

44. Agency, X.N. Xi Jinping Attended the Opening Ceremony of the "Belt and Road" International Cooperation Summit Forum and Delivered a Keynote Speech; Xinhua News Agency Beijing: Beijing, China, 2017.

45. Government Malawi. Malawi 2020 Voluntary National Review Report for Sustainable Development Goals(SDGs); Government Malawi: Lilongwe, Malawi, 2020.

46. Government Sierra Leone. 2019 vnr Report on SDGs in Sierra Leone; Government Sierra Leone: Freetown, Sierra Leone, 2019.

47. Government Bhutan. Sustainable Development and Happiness: Bhutan's Voluntary National Review Report on the Implementation of the 2030 Agenda for Sustainable Development; Government Bhutan: Thimphu, Bhutan, 2018.

48. Government Zambia. Zambia: Sustainable Development Goals Voluntary National Review 2020; Ministry of National Development Planning: Lusaka, Zambia, 2020.

49. Government Turkey. Turkey's 2nd vnr 2019 Sustainable Development Goals "Strong Ground towards Common Goals"; Government Turkey: Ankara, Turkey, 2019.

50. Government Afghanistan. Voluntary National Review at the High Level Political Forum SDGs' Progress Report: Afghanistan; Government Afghanistan: Kabul, Afghanistan, 2017.

51. Government Pakistan. Pakistan's Implementation of the 2030 Agenda for Sustainable Development Voluntary National Review; Government Pakistan: Islamabad, Pakistan, 2019.

52. Government Ethiopia. The 2017 Voluntary National Reviews on SDGs of Ethiopia: Government Commitments, National Ownership and Performancetrends; National Plan Commission, Government Ethiopia: Addis Ababa, Ethiopia, 2017.

53. Government Bangladesh. Bangladesh Voluntary National Reviews (vnrs) 2020. Accelerated Action and Transformative Pathways: Realizing the Decade of Action and Delivery for Sustainable Development; Government Bangladesh: Dhaka, Bangladesh, 2020.

54. Caiado, R.G.G.; Leal Filho, W.; Quelhas, O.L.G.; de Mattos Nascimento, D.L.; Ávila, L.V. A literature-based review on potentials and constraints in the implementation of the sustainable development goals. J. Clean. Prod. 2018, 198, 1276-1288. [CrossRef]

55. Government Laos. Lao People's Democratic Republic: Voluntary National Review on the Implementation of the 2030 Agenda for Sustainable Development; Government Laos: Vientiane, Laos, 2018.

56. Government Thailand. Thailand's Voluntary National Review on the Implementation of the 2030 Agenda for Sustainable Development; Government Thailand: Bangkok, Thailand, 2017.

57. Government Greece. Voluntary National Review on the Implementation of the 2030 Agenda for Sustainable Development; General Secretariat of the Government, Office of Coordination, Institutional, International \& European Affairs, Government Greece: Athens, Greece, 2018.

58. Government Kenya. Second Voluntary National Review on the Implementation of the Sustainable Development Goals; Government Kenya: Nairobi, Kenya, 2020.

59. Government Kazakhstan. Kazakhstan Voluntary National Review 2019 on the Implementation of the 2030 Agenda for Sustainable Development; Government Kazakhstan: Nur Sultan, Kazakhstan, 2019.

60. Government South Africa. 2019 South Africa Voluntary National Review: Empowering People and Ensuring Inclusiveness and Equality; Government South Africa: Tshwane, South Africa, 2019.

61. Government Spain. Spain's Report for the 2018 Voluntary National Review; Government Spain: Madrid, Spain, 2018.

62. Tittensor, D.P.; Walpole, M.; Hill, S.L.L.; Boyce, D.G.; Britten, G.L.; Burgess, N.D.; Butchart, S.H.M.; Leadley, P.W.; Regan, E.C.; Alkemade, R.; et al. A mid-term analysis of progress toward international biodiversity targets. Science 2014, 346, $241-244$. [CrossRef]

63. Government Romania. Transformation towards a Sustainable and Resilient Romania: Romania's Voluntary National Review 2018; Government Romania: Bucharest, Romania, 2018.

64. Razzaq, S.; Chaudhry, K.; Tabassum, R.; Kunwal, N.; Najafizada, S.A.M.; Acharya, S.S.; Ellepola, Y.; Chowdhury, M.E.; Neupane, S.; Kumar, B.C.R.; et al. National level preparedness for implementing the health-related sustainable development goals (SDGs) in seven south asian countries: Afghanistan, bangladesh, bhutan, india, pakistan, nepal and sri lanka. Glob. Policy 2020, 11, 191-201. [CrossRef] 
65. Government Germany. German Sustainable Development Strategy: New Version 2016. Available online: https:// www.bundesregierung.de/resource/blob/997532/188836/7d1716e5d5576bec62c9d16ca908e80e/2017-06-20-nachhaltigkeitneuauflage-engl-data.pdf?download=1 (accessed on 12 July 2020).

66. Government Israel. Implemention of the Sustainable Development Goals: National Review, Israel 2019; Government Israel: Jerusalem, Israel, 2019.

67. Government Finland. Report on the Implementation of the 2020 Agenda for Sustainable Develoment; Prime Minister's Office, Government Finland: Helsinki, Finland, 2020.

68. Government Japan. Japan's Voluntary National Review Report on the Implementation of the Sustainable Development Goals; Government Japan: Tokyo, Japan, 2017.

69. Government Liberia. Liberia: Voluntary National Review on the Implementation Status of the 2030 Agenda for Sustainable Development, 2020; Government Liberia: Monrovia, Liberia, 2020.

70. Government Nepal: National Review of Sustainable Development Goals; Government Nepal: Kathmandu, Nepal, 2020.

71. Allen, C.; Metternicht, G.; Wiedmann, T. Initial progress in implementing the sustainable development goals (SDGs): A review of evidence from countries. Sustain. Sci. 2018, 13, 1453-1467. [CrossRef]

72. Government Tajikistan. Improving Living Standards through Mainstreaming of Sustainable Development Goals into the National Development Policy in Tajikistan; Government Tajikistan: Dushanbe, Tajikistan, 2017.

73. Sachs, J.; Schmidt-Traub, G.K.C.; Lafortune, G.; Fuller, G.; Woelm, F. The Sustainable Development Goals and COVID-19. Sustainable Development Report 2020; Cambridge University Press: Cambridge, UK, 2020.

74. Kristensen, F.B.; Makela, M.; Neikter, S.A.; Rehnqvist, N.; Haheim, L.L.; Morland, B.; Milne, R.; Nielsen, C.P.; Busse, R.; Lee-Robin, S.H.; et al. European network for health technology assessment, eunethta: Planning, development, and implementation of a sustainable european network for health technology assessment. Int. J. Technol. Assess. Health Care 2009, 25, 107-116. [CrossRef]

75. Popovic, B.; Soja, S.J.; Paunovic, T.; Maletic, R. Evaluation of sustainable development management in EU countries. Sustainability 2019, 11, 7140. [CrossRef]

76. G20. G20 Action Plan on the 2030 Agenda for Sustainable Development; G20: Hangzhou, China, 2016.

77. Leal, W.; Brandli, L.L.; Salvia, A.L.; Rayman-Bacchus, L.; Platje, J. Covid-19 and the UN sustainable development goals: Threat to solidarity or an opportunity? Sustainability 2020, 12, 5343. [CrossRef]

78. Barbier, E.B.; Burgess, J.C. Sustainability and development after COVID-19. World Dev. 2020, 135, 105082. [CrossRef]

79. Editorial. Time to revise the sustainable development goals. Nature 2020, 583, 331-332. [CrossRef] [PubMed]

80. The UN Department of Economic and Social Affairs (UN DESA). Everyone Included: Social Impact of Covid-19. Available online: https:/ / www.un.org/development/desa/dspd/everyone-included-covid-19.html (accessed on 23 May 2021).

81. Ottersen, O.P.; Engebretsen, E. Covid-19 puts the sustainable development goals center stage. Nat. Med. 2020, 26, 1672-1673. [CrossRef]

82. Gulseven, O.; Al Harmoodi, F.; Al Falasi, M.; ALshomali, I. How the COVID-19 Pandemic Will Affect the UN Sustainable Development Goals? Available online: https://papers.ssrn.com/sol3/papers.cfm?abstract_id=3592933 (accessed on 1 May 2021).

83. Nilsson, M.; Chisholm, E.; Griggs, D.; Howden-Chapman, P.; McCollum, D.; Messerli, P.; Neumann, B.; Stevance, A.-S.; Visbeck, M.; Stafford-Smith, M. Mapping interactions between the sustainable development goals: Lessons learned and ways forward. Sustain. Sci. 2018, 13, 1489-1503. [CrossRef]

84. Tremblay, D.; Fortier, F.; Boucher, J.F.; Riffon, O.; Villeneuve, C. Sustainable development goal interactions: An analysis based on the five pillars of the 2030 agenda. Sustain. Dev. 2020, 28, 1584-1596. [CrossRef]

85. Pham-Truffert, M.; Metz, F.; Fischer, M.; Rueff, H.; Messerli, P. Interactions among sustainable development goals: Knowledge for identifying multipliers and virtuous cycles. Sustain. Dev. 2020, 28, 1236-1250. [CrossRef]

86. Abson, D.J.; Fischer, J.; Leventon, J.; Newig, J.; Schomerus, T.; Vilsmaier, U.; Von Wehrden, H.; Abernethy, P.; Ives, C.D.; Jager, N.W. Leverage points for sustainability transformation. Ambio 2017, 46, 30-39. [CrossRef]

87. Breuer, A.; Janetschek, H.; Malerba, D. Translating sustainable development goal (SDG) interdependencies into policy advice. Sustainability 2019, 11, 2092. [CrossRef]

88. Jain, P.; Jain, P. Are the sustainable development goals really sustainable? A policy perspective. Sustain. Dev. 2020, $28,1642-1651$. [CrossRef]

89. Scharlemann, J.P.W.; Brock, R.C.; Balfour, N.; Brown, C.; Burgess, N.D.; Guth, M.K.; Ingram, D.J.; Lane, R.; Martin, J.G.C.; Wicander, S.; et al. Towards understanding interactions between sustainable development goals: The role of environment-human linkages. Sustain. Sci. 2020, 15, 1573-1584. [CrossRef]

90. Liu, H.; Fang, C.; Fang, K. Coupled human and natural cube: A novel framework for analyzing the multiple interactions between humans and nature. J. Geogr. Sci. 2020, 30, 355-377. [CrossRef]

91. Nerini, F.F.; Sovacool, B.; Hughes, N.; Cozzi, L.; Cosgrave, E.; Howells, M.; Tavoni, M.; Tomei, J.; Zerriffi, H.; Milligan, B. Connecting climate action with other sustainable development goals. Nat. Sustain. 2019, 2, 674-680. [CrossRef]

92. Mi, Z.; Wei, Y.-M.; Wang, B.; Meng, J.; Liu, Z.; Shan, Y.; Liu, J.; Guan, D. Socioeconomic impact assessment of China's co2 emissions peak prior to 2030. J. Clean. Prod. 2017, 142, 2227-2236. [CrossRef]

93. Nilsson, M.; Griggs, D.; Visbeck, M. Policy: Map the interactions between sustainable development goals. Nature 2016, 534, 320-322. [CrossRef] [PubMed]

94. Stafford-Smith, M. UN sustainability goals need quantified targets. Nature 2014, 513, 281. [CrossRef] 
95. United Nations. Global Sustainable Development Report 2019: The Future is Now-Science for Achieving Sustainable Development; United Nations: New York, NY, USA, 2019.

96. Sachs, J.D.; Schmidt-Traub, G.; Mazzucato, M.; Messner, D.; Nakicenovic, N.; Rockstrom, J. Six transformations to achieve the sustainable development goals. Nat. Sustain. 2019, 2, 805-814. [CrossRef]

97. Ferrannini, A.; Barbieri, E.; Biggeri, M.; Di Tommaso, M.R. Industrial policy for sustainable human development in the postcovid19 era. World Dev. 2021, 137, 15. [CrossRef]

98. Maurya, S.P.; Singh, P.K.; Ohri, A.; Singh, R. Identification of indicators for sustainable urban water development planning. Ecol. Indic. 2020, 108, 9. [CrossRef]

99. Lusseau, D.; Mancini, F. Income-based variation in sustainable development goal interaction networks. Nat. Sustain. 2019, 2, 242-247. [CrossRef]

100. Pradhan, P.; Costa, L.; Rybski, D.; Lucht, W.; Kropp, J.P. A systematic study of sustainable development goal (SDG) interactions. Earths Future 2017, 5, 1169-1179. [CrossRef]

101. Voyer, M.; Farmery, A.K.; Kajlich, L.; Vachette, A.; Quirk, G. Assessing policy coherence and coordination in the sustainable development of a blue economy. A case study from timor leste. Ocean Coast. Manag. 2020, 192, 16. [CrossRef]

102. Kanie, N.; Griggs, D.; Young, O.; Waddell, S.; Shrivastava, P.; Haas, P.M.; Broadgate, W.; Gaffney, O.; Korosi, C. Rules to goals: Emergence of new governance strategies for sustainable development governance for global sustainability is undergoing a major transformation from rule-based to goal-based. But with no compliance measures, success will require an unprecedented level of coherency of action founded on new and reformed institutions nationally and internationally. Sustain. Sci. 2019, 14, 1745-1749.

103. Mukherjee, A.; Babu, S.S.; Ghosh, S. Thinking about water and air to attain sustainable development goals during times of covid-19 pandemic. J. Earth Syst. Sci. 2020, 129, 8. [CrossRef]

104. Dolley, J.; Marshall, F.; Butcher, B.; Reffin, J.; Robinson, J.A.; Eray, B.; Quadrianto, N. Analysing trade-offs and synergies between SDGs for urban development, food security and poverty alleviation in rapidly changing peri-urban areas: A tool to support inclusive urban planning. Sustain. Sci. 2020, 15, 1601-1619. [CrossRef]

105. Mulligan, M.; van Soesbergen, A.; Hole, D.G.; Brooks, T.M.; Burke, S.; Hutton, J. Mapping nature's contribution to SDG 6 and implications for other SDGs at policy relevant scales. Remote Sens. Environ. 2020, 239, 10. [CrossRef]

106. Assuad, C.S.A. Understanding rationality in sustainable development decision-making: Unfolding the motivations for action. J. Knowl. Econ. 2020, 11, 1086-1119. [CrossRef]

107. Bobylev, S.; Grigoryev, L. In Search of the Contours of the Post-Covid Sustainable Development Goals: The Case of Brics; MPRA Paper 102424; University Library of Munich, Germany: Munich, Germany, 2020.

108. Reckien, D.; Creutzig, F.; Fernandez, B.; Lwasa, S.; Tovar-Restrepo, M.; McEvoy, D.; Satterthwaite, D. Climate change, equity and the sustainable development goals: An urban perspective. Environ. Urban. 2017, 29, 159-182. [CrossRef]

109. United Nations. Policy Brief on COVID-19 in an Urban World. Available online: https://unhabitat.org/un-secretary-general\%E2 $\% 80 \% 99$ s-policy-brief-on-covid-19-in-an-urban-world (accessed on 16 August 2020).

110. Mukarram, M. Impact of covid-19 on the UN sustainable development goals (SDGs). Strateg. Anal. 2020, 44, 253-258. [CrossRef]

111. Meng, H.; Gao, X.; Song, Y.; Cao, G.; Li, J. Biodiversity arks in the anthropocene. Reg. Sustain. 2021, 2, $109-115$.

112. Mbanda, V.; Fourie, W. The 2030 agenda and coherent national development policy: In dialogue with south african policymakers on policy coherence for sustainable development. Sustain. Dev. 2020, 28, 751-758. [CrossRef]

113. Koff, $\mathrm{H}$. Why serve soup with a fork?: How policy coherence for development can link environmental impact assessment with the 2030 agenda for sustainable development. Environ. Impact Assess. Rev. 2021, 86, 10. [CrossRef]

114. Fourie, W. Aligning south africa's national development plan with the 2030 agenda's sustainable development goals: Guidelines from the policy coherence for development movement. Sustain. Dev. 2018, 26, 765-771. [CrossRef]

115. Delany-Crowe, T.; Marinova, D.; Fisher, M.; McGreevy, M.; Baum, F. Australian policies on water management and climate change: Are they supporting the sustainable development goals and improved health and well-being? Global. Health 2019, 15, 15. [CrossRef]

116. Foro, C. The Forum of the Countries of Latin America and the Caribbean on Sustainable Development. Available online: https:/ / agenda2030lac.org/en/forum-countries-latin-america-and-caribbean-sustainable-development-and-regional-follow2030-agenda (accessed on 1 May 2021).

117. UN Environment Programme. Measuring Progress: Environment and the SDGs; UN Environment Programme: Nairobi, Kenya, 2021.

118. Ekins, P.; Simon, S.; Deutsch, L.; Folke, C.; De Groot, R. A framework for the practical application of the concepts of critical natural capital and strong sustainability. Ecol. Econ. 2003, 44, 165-185. [CrossRef]

119. Hak, T.; Janouskova, S.; Moldan, B. Sustainable development goals: A need for relevant indicators. Ecol. Indic. 2016, 60, 565-573. [CrossRef]

120. Zhou, C.; Su, F.; Pei, T.; Zhang, A.; Du, Y.; Luo, B.; Cao, Z.; Wang, J.; Yuan, W.; Zhu, Y. Covid-19: Challenges to gis with big data. Geogr. Sustain. 2020, 1, 77-87. [CrossRef]

121. Wang, S.; Tong, Y.; Fan, Y.; Liu, H.; Wu, J.; Wang, Z.; Fang, C. Silent World under Covid-19—A Comprehensive Impact Analysis Based on Human Mobility. Researchsquare 2021. [CrossRef]

122. Guo, H.; Nativi, S.; Liang, D.; Craglia, M.; Wang, L.; Schade, S.; Corban, C.; He, G.; Pesaresi, M.; Li, J.; et al. Big earth data science: An information framework for a sustainable planet. Int. J. Digit. Earth 2020, 13, 743-767. [CrossRef] 
123. Altan, O.; Dowman, I. The changing world under the corona virus threat-From human needs to SDGs and what next? Geo-Spat. Inf. Sci. 2021, 24, 1-8. [CrossRef]

124. Kavvada, A.; Metternicht, G.; Kerblat, F.; Mudau, N.; Haldorson, M.; Laldaparsad, S.; Friedl, L.; Held, A.; Chuvieco, E. Towards delivering on the sustainable development goals using earth observations. Remote Sens. Environ. 2020, 247, 111930. [CrossRef]

125. Liu, H.; Fang, C.; Gao, Q. Evaluating the real-time impact of covid-19 on cities: China as a case study. Complexity $2020,8855521$. [CrossRef]

126. Shepherd, K.; Hubbard, D.; Fenton, N.; Claxton, K.; Luedeling, E.; de Leeuw, J. Policy: Development goals should enable decision-making. Nature 2015, 523, 152-154. [CrossRef] [PubMed]

127. Wamsler, C.; Johannessen, A. Meeting at the crossroads? Developing national strategies for disaster risk reduction and resilience: Relevance, scope for, and challenges to, integration. Int. J. Disaster Risk Reduct. 2020, 45, 8. [CrossRef]

128. Alcamo, J.; Thompson, J.; Alexander, A.; Antoniades, A.; Delabre, I.; Dolley, J.; Marshall, F.; Menton, M.; Middleton, J.; Scharlemann, J.P.W. Analysing interactions among the sustainable development goals: Findings and emerging issues from local and global studies. Sustain. Sci. 2020, 15, 1561-1572. [CrossRef]

129. Croese, S.; Green, C.; Morgan, G. Localizing the sustainable development goals through the lens of urban resilience: Lessons and learnings from 100 resilient cities and cape town. Sustainability 2020, 12, 16. [CrossRef]

130. Ng, M.K. Sustainable development goals (SDGs) and pandemic planning. Plan. Theory Pract. 2020, 21, 507-512. [CrossRef]

131. Diz, D.; Morgera, E.; Wilson, M. Marine policy special issue: SDG synergies for sustainable fisheries and poverty alleviation. Mar. Policy 2019, 110, 2. [CrossRef]

132. Buyana, K. Keeping the doors open: Experimenting science-policy-practice interfaces in africa for sustainable urban development. J. Hous. Built Environ. 2020, 35, 539-554. [CrossRef]

133. Turnheim, B.; Asquith, M.; Geels, F.W. Making sustainability transitions research policy-relevant: Challenges at the science-policy interface. Environ. Innov. Soc. Transit. 2020, 34, 116-120. [CrossRef]

134. Scown, M.W.; Winkler, K.J.; Nicholas, K.A. Aligning research with policy and practice for sustainable agricultural land systems in europe. Proc. Natl. Acad. Sci. USA 2019, 116, 4911-4916. [CrossRef]

135. Colglazier, E.W. Response to the covid-19 pandemic: Catastrophic failures of the science-policy interface. Sci. Dipl. 2020, 9. Available online: https://www.sciencediplomacy.org/editorial/2020/response-covid-19-pandemic-catastrophic-failuresscience-policy-interface (accessed on 1 May 2021).

136. Allen, C.; Metternicht, G.; Wiedmann, T. National pathways to the sustainable development goals (SDGs): A comparative review of scenario modelling tools. Environ. Sci. Policy 2016, 66, 199-207. [CrossRef]

137. The Global Goals. 2030 Vision: Uniting to Deliver Technology for the Global Goals; SustainAbility: London, UK, 2017.

138. The Global Enabling Sustainability Initiative (GeSI). Digital with Purpose: Delivering a Smarter 2030; The Global Enabling Sustainability Initiative (GeSI): Brussels, Belgium, 2019.

139. Fukuda, K. Science, technology and innovation ecosystem transformation toward society 5.0. Int. J. Prod. Econ. 2020, 220, 107460. [CrossRef]

140. Vinuesa, R.; Azizpour, H.; Leite, I.; Balaam, M.; Dignum, V.; Domisch, S.; Felländer, A.; Langhans, S.D.; Tegmark, M.; Fuso Nerini, F. The role of artificial intelligence in achieving the sustainable development goals. Nat. Commun. 2020, 11, 233. [CrossRef]

141. Liu, H.; Fang, C.; Sun, S. Digital inequality in provincial china. Environ. Plan A 2017, 49, 2179-2182. [CrossRef]

142. Reynolds, M.; Blackmore, C.; Ison, R.; Shah, R.; Wedlock, E. The role of systems thinking in the practice of implementing sustainable development goals. In Handbook of Sustainability Science and Research; Leal Filho, W., Ed.; Springer International Publishing: Cham, Switzerland, 2018; pp. 677-698.

143. Bowen, K.J.; Cradock-Henry, N.A.; Koch, F.; Patterson, J.; Häyhä, T.; Vogt, J.; Barbi, F. Implementing the "sustainable development goals": Towards addressing three key governance challenges—collective action, trade-offs, and accountability. Curr. Opin. Environ. Sustain. 2017, 26, 90-96. [CrossRef]

144. Claudet, J.; Bopp, L.; Cheung, W.W.; Devillers, R.; Escobar-Briones, E.; Haugan, P.; Heymans, J.J.; Masson-Delmotte, V.; Matz-Lück, N.; Miloslavich, P. A roadmap for using the UN decade of ocean science for sustainable development in support of science, policy, and action. One Earth 2020, 2, 34-42. [CrossRef]

145. Rozhenkova, V.; Allmang, S.; Ly, S.; Franken, D.; Heymann, J. The role of comparative city policy data in assessing progress toward the urban SDG targets. Cities 2019, 95, 8. [CrossRef]

146. Li, Q. Resilience thinking as a system approach to promote china's sustainability transitions. Sustainability 2020, $12,5008$. [CrossRef] 